Portland State University

PDXScholar

$1-1-2019$

\title{
How Does the Primary Market Value Innovations of Newly Public Firms?
}

Qin Lian

Portland State University, qlian@pdx.edu

Qiming Wang

Willamette University

Follow this and additional works at: https://pdxscholar.library.pdx.edu/busadmin_fac

Part of the Business Commons

Let us know how access to this document benefits you.

\section{Citation Details}

Lian, Q., \& Wang, Q. (2019). How Does the Primary Market Value Innovations of Newly Public Firms? Journal of Accounting, Auditing \& Finance, 34(1), 3-29. https://doi.org/10.1177/0148558X16665964

This Post-Print is brought to you for free and open access. It has been accepted for inclusion in Business Faculty Publications and Presentations by an authorized administrator of PDXScholar. Please contact us if we can make this document more accessible: pdxscholar@pdx.edu. 


\title{
How does the primary market value innovations of newy public firms?
}

\begin{abstract}
We investigate whether and how the primary market values the innovations of newly public firms at their IPOs by examining the link between the size (the number of patents) and the quality (citation count) of their patent portfolios and IPO valuations. We find that the number of patents, the citation count, and innovation efficiency (patents or citations scaled by research and development expenditure) are positively associated with offer price multiples but the effect of the number of patents subsumes that of the citation count/innovation efficiency. There is no significant effect of patent portfolios on price revisions or first-day returns, suggesting that underwriters/firms price information on innovation quantity and quality in the offer prices and the market makes no further price adjustment on innovation information. The positive effect of innovation quantity on IPO valuation subsumes that of innovation quality. We also demonstrate that the link between patent portfolios and IPO valuations is stronger in the later sample period. Using Tobin's Q as another IPO valuation measure produces similar results. We obtain no evidence that an IPO's patent portfolio is overvalued in the primary market, as the number of patents and the citation count are not significantly associated with long-run stock and operating performances.
\end{abstract}

Keywords: innovation output; IPO valuations; patents; citation count; innovation efficiency; Tobin's Q

JEL Codes: G30; G32 


\section{Introduction}

Recent studies have found that firms reach the apex of their innovative activities at the time of their IPOs (Bernstein, 2015), and firms often choose to go public following an innovative breakthrough (Pastor, Taylor, and Veronesi, 2009). This phenomenon leads us to ask how the primary market values the innovations of newly public firms at their IPOs. While IPO valuations have been examined extensively in the literature, less is known about the link between innovation and IPO valuation. This question is particularly relevant given that the composition of R\&D investment has significantly shifted away from federal funding to private funding since $1960^{1}$ and young firms' reliance on public equity issuances to fund R\&D investment has increased over the past decades (Brown, Fazzari, and Petersen, 2009).

Innovations boost market share, provide competitive advantage, and increase earnings. Previous studies document that innovations are valued in the secondary market. However, it is not clear how the primary market incorporates IPO firms' innovation capability, measured by the size (the number of patents), quality (citation count), and innovation efficiency of their patent portfolio. The primary market may underestimate valuation information in patents of IPO firms. Technological information about a patent is hard to decipher for most investors. In addition, evaluating the value of patents requires analyzing the patent, product development and the launch of the product on the market, the profit of which can be highly uncertain and long deferred. Further, the distribution of patent values is highly skewed, with a few patents having a very high value and a large number of patents having low value. Several studies have shown that the market seems to underreact to valuation information regarding seasoned firms' patents. Gu (2005) finds that changes in scaled patent citations are positively associated with firms' future stock returns. Matcolcsy and Wyatt (2008) find that patent count at the industry level is

\footnotetext{
${ }^{1}$ See the CongressionalBudget Office's 2005 report entitled "R\&D and Productivity Growth".
} 
positively associated with contemporaneous market valuations. Cohen, Diether, and Malloy (2013) find that firms with past success in innovation (measured as how firms turn R\&D into future sales) outperform other firms that invest the same amount in R\&D. Hirshleifer, Hsu, and Li (2012) document a positive relationship between innovative efficiency (patents or citations scaled by $R \& D$ expenditures) and future stock returns. If the market fails to fully value innovations for seasoned firms with more predictable and persistent performance, the primary market is likely to undervalue innovation for these newly public IPO firms with less certain future, leading to a positive relation between innovation and future stock returns for IPOs. ${ }^{2}$

On the other hand, the primary market may overestimate valuation information in patents of IPO firms, as investors may be overoptimistic about the contribution of patents to the future performance of IPO firms. This view is consistent with the finding that R\&D-intensive firms tend to be overpriced as investors overestimate the benefits from R\&D or simply ignore the fact that many R\&D investments are not profitable (Jensen (1993)). Similarly, Daniel and Titman (2006) show that growth stock underperformance is concentrated in stocks with significant "intangible" information, consistent with market overreaction to intangible information that is difficult to interpret. Loughran and Ritter (1995) document long-run underperformance of IPO firms, suggesting that investors are overoptimistic about the prospects of firms when they go public. Purnandam and Swaminathan (2004) document that investors are deceived by optimistic growth forecasts and overvalue IPOs with high growth potential. Investors may over extrapolate IPO firms' earnings growth based on their patent portfolios, leading to innovation being overpriced at the IPO and hence to a negative relation between innovation and future stock

\footnotetext{
2 Hirshleifer, Hsu, and $\mathrm{Li}$ (2012) find a stronger innovation efficiency-stock return relation among young and smaller seasoned firms.
} 
returns for IPO firms. Therefore, whether the primary market overvalues or undervalues innovations of IPOs is an empirical question.

In this paper, we analyze a sample of 4,795 IPOs during the period 1981-2006 to examine whether and how the primary market values innovations of IPO firms at the time of offering. First, we investigate the effects of the presence and various measures of patent portfolios on IPO valuation ratios to examine whether underwriters/issuers incorporate pre-IPO patent portfolios to set IPO valuations. We find that firms with patents expect and receive significantly higher valuations than firms without patents when filing for an IPO after controlling for firm and issue characteristics. For IPOs with patents, the number of patents, citation count, and innovation efficiency are positively associated with IPO valuation ratios after extensive controls but that the effect of the number of patents subsumes that of the citation count and innovation efficiency. ${ }^{3}$ The size of patent portfolios is the dominant factor in IPO valuations. Splitting the sample into two sub-periods, 1981-1993 and 1993-2006, we find a positive effect of patent portfolios on valuations in both periods but that the effect is significant only in the second sub-period. This evidence suggests that markets (underwriters) have improved their ability to value patents for IPO firms.

Second, we investigate how various measures of patent portfolios are related to short/long run IPO performances to examine whether the market undervalue or overvalue innovations of IPOs based the market reaction to the valuation effect of patent portfolios for IPOs. We find that these patent-related factors have no effect on initial returns, a measure of valuation adjustment from IPO prices during the first trading day after offerings. We also document that there is no significant association between the number of patents/citation count

\footnotetext{
${ }^{3}$ These regressions control for industry valuation, industry adjusted operating performance, leverage, R\&D, sales growth, venture capitalist backing, firm age, underwriter reputation, and industry and year effects.
} 
and abnormal buy-and-hold returns up to three years after IPOs. Finally, we find no relation between post-IPO operating performances and the size and quality of patent portfolios at IPOs. Overall, these findings suggest that IPOs with larger patent portfolios are not underpriced or overpriced in the primary market, leading to no abnormal long-run stock performance in the secondary equity market.

By examining whether and how the primary market prices patent portfolios of IPOs, our paper adds to the growing literature on innovation and IPO valuation. Specifically, using a more general sample over a longer time period, we measure IPO firms' innovations with a host of patent-related measures and focus on the effect of innovations on IPO valuation multiples at different stages of the IPO process. That leads to two significant new findings. First, pre-IPO innovation seems to be priced correctly in the IPO process as the number of patents and the citation count are not significantly associated with short/long-run stock performances, i.e., there are no incremental returns associated with pre-IPO patent portfolios in the aftermarket. Second, all measures of patent portfolios have positive effects but the size of patent portfolios is the dominant factor in IPO valuations, possibly because technological information about a patent is hard to decipher but the number of patents is a simple and easier concept to grasp.

Early studies often use the input of innovations - R\&D expenditure. For example, Guo, Lev, and Shi (2006) focus on the link between R\&D expenditure and IPO underpricing and longrun performance. They find $\mathrm{R} \& \mathrm{D}$ is positively related to long-term performance. Several recent studies examine IPO pricing and the innovation output, i.e., the patent. Most use patent counts as a measure of information asymmetry and focus on the relationship between patent counts and short/long run performance. Guo, Lev, and Zhou (2005) study 122 biotech IPOs during the period 1991-2000 and find that firms with more patent-protection products are associated with 
higher underpricing and lower long-run stock return. They interpret this as over optimism regarding patent protection at the time of IPOs. Heeley, Matusik, and Jain (2007) study 1,413 manufacturing IPOs from 1981 to 1998. They find that patents reduce underpricing in the industries where the link between patents and returns is transparent, such as the pharmaceutical sector, while patents increase underpricing in the industries where the link is complex, similar to the computer sector. Bessler and Bittelmeyer (2008) study 287 German IPOs from 1997 to 2002, of which 90 firms have patents. They find underpricing of IPOs with patents is lower relative to the group of IPOs without patents in hot markets. The relationship is reversed in cold markets. They also find high abnormal long-run returns for IPOs with patents compared to IPOs without patents.

Our paper also adds to the literature on innovation activity and IPO. Ferreira, Manso, and Silva (2012) develop a theoretical model showing that private ownership encourages firm innovation. Bernstein (2015) finds that firms' internal innovations go down after their IPOs. Tian and Wang (2011) find that IPOs backed by more failure tolerant VCs are more innovative. Barnanchuk, Kieschnick, and Moussawi (2014) show that incentive compensation, long vesting periods for unexercised options, and tolerance for failure motivate managers to pursue innovation in IPO firms after their offerings.

The rest of the paper proceeds as follows. Section 2 describes the data sources and sample. Section 3 presents the results. Section 4 concludes.

\section{Sample and Data}

This section discusses IPO sample selection, patent metrics as measures of innovations, and the summary statistics comparing IPOs with and without patents at the time of IPOs. 


\subsection{IPO sample selection}

We use the Securities Data Corporation Global New Issues Database (hereafter, SDC) to identify all IPOs from January 1, 1981 to December $31,2006 .{ }^{4}$ After correcting mistakes and typographical errors in the SDC database according to Jay Ritter's procedure (http://bear.warrington.ufl.edu/ritter/ipodata.htm), we eliminate financial firms (SIC codes between 6000 and 6999), utilities firms (SIC codes between 4900 and 4999), unit offer, closedend funds (including REIT), ADR, limited partnerships, special acquisition vehicles, and spinoffs. We then require IPOs to have pre-IPO accounting information available from Compustat. Following this procedure, we identify 4,795 completed IPOs during the period 1981-2006.

\subsection{Patent measures}

We use patent related metrics to measure firms' pre-IPO innovation activities because patents are successful outcomes of past research and development efforts (Hall, Jaffe, and Trajtenberg, 2001). Patents enable firms to maintain a competitive advantage for a lasting period of time and are intrinsically valuable. The patent variables are constructed from the latest version of the National Bureau of Economic Research (NBER) patent database. The database was initially created by Hall, Jaffe, and Trajtenberg (2001) and contains updated patent and citation information from 1976 to 2006 . Following the literature, we focus only on utility patent grants rather than other awards, such as design or reissue awards. Utility patents represent approximately 99\% of all awards (Lerner, Sorensen, and Stromberg, 2011).

The NBER patent database contains detailed information on all US patents granted by the US Patent and Trademark Office (USPTO): patent assignee names, firms' Compustat identifiers (GVKEY), and the number of citations received by each patent, application year, grant dates, and

\footnotetext{
${ }^{4}$ Our IPO sample begins in 1981 because the National Bureau of Economic Research (NBER) patent database starts from 1976, and we examine an IPO's patents from 5 years prior to its offering to the offering date.
} 
other details. We use 6-digit Cusip for each IPO from SDC to match historical CUSIP variables in CRSP and Compustat to retrieve CRSP Permno and Compustat GVKEY. We then use GVKEY to match NBER patent data. We also use company names and ticker symbol to verify our matching accuracy.

To prevent any potential look-ahead bias, we follow Hirshleifer, Hsu, and Li (2012) and choose the grant date as the effective date of each patent. We use patents in the five years prior to the IPO to proxy for the firm's pre-IPO innovative capability. The basic measure of innovation output is a simple count of patent grants in the five years before the IPO date to capture the quantity of patents. Following Bernstein (2015) and Bena and Li (2014), we calculate the scaled patent count, as patent grants vary over time and across technologies. First, for each technology class $^{5}$ defined by USPTO and the patent grant year, we compute the average number of granted patents of all firms in its technology class within that grant year. Second, we scale the number of patents granted to the firm in the technology class in that year by the corresponding average value for that technology class and grant year from the first step. Third, for each firm, we sum the scaled number of granted patents from the second step across all technology classes and across 5 years prior to the IPO dates. Lastly, we use scaled number of patents divided by total assets in the fiscal year immediately before the IPO to control for the size effect.

We also use citation count - the number of citations a patent receives after its approval as another measure of innovation output because the importance of patents varies. We calculate citations for patents granted over the five years prior to IPO dates. The citation count is the number of citations a patent receives upon its approval to the IPO year. We adjust for time and

\footnotetext{
${ }^{5}$ Technology classes are defined by the USPTO to capture the technological essence of an invention. Technological classes are often more detailed than industry classifications, with about 400 main (3-digit) patent classes and over 120,000 patent subclasses.
} 
technology variation by scaling each patent citation count by the average number of citations received by all patents granted in the same year and technology class. For firm i, we calculate $C_{i k}^{j}$, the number of citations received in year $\mathrm{j}(\mathrm{j}=\max (-5$, grant year-IPO year) to $\mathrm{j}=0$, year 0 is the IPO year) by patent $\mathrm{k}$, scaled by the average number of citations received in year $\mathrm{j}$ by all patents of the same technology class granted in the same year. Second, we sum scaled citations for IPO firm i's patents granted over the five years before its IPO date as following:

$$
\text { Scaled } \text { Citation }_{i}=\sum_{j=\max (-5, \text { grant year-IPO year })}^{0} \sum_{k=1}^{N_{j}} C_{i k}^{j}
$$

The final measure, innovation efficiency (IE), compares patent count or citation to $R \& D$ expenses (Hirshleifer, Hsu, and Li, 2012). Patents and citations are the output of the innovation process. R\&D measures the innovation input. Innovation efficiency measures a firm's ability to generate patents and patent citations per dollar of $R \& D$ expenditure. We use two proxies for innovation efficiency: scaled number of patents and scaled current citations divided by R\&D expenses in the year prior to the IPO dates (Innovation efficiency-Pat and Innovation efficiencyCitation). ${ }^{6}$

\subsection{Other control variables}

For our multivariate regressions, we include several other control variables from the literature in an attempt to isolate the portion of the IPO valuation or firm performance that is related to an IPO's patent portfolio. Following Bhojraj and Lee (2002), we use $P S_{\text {ind }}$, the industry (based on the two-digit primary SIC code) median ratio of market value divided by total sales for

\footnotetext{
${ }^{6}$ We thank an anonymous referee who suggested this additional innovation measure. Hirshleifer, Hsu, and Li (2013) use 5-year cumulative R\&D expenses assuming an annual depreciation rate of $20 \%$ in the fiscal year ending 2 years before its patent approval to calculate their innovation efficiency meas ures. For our sample of 922 IPOs with patents, we use R\&D expenses in the year prior to the IPO date to compute innovation efficiency because only 321 and 45 firms have information on R\&D expenses in the fiscal year ending 2 years and 3 years before their IPO dates, respectively.
} 
the IPO year, to proxy industry valuation. In addition, we include other valuation factors to control for firms' operating performance and leverage. Prior industry-adjusted OPA equals the difference between the IPO firm's OPA and the median OPA of its industry. The Leverage is defined as the ratio of total liabilities over total assets. Poulsen and Stegemoller (2008) show that private firms with higher growth potential choose an IPO instead of being acquired and valuation ratios for IPOs are significantly higher than those of comparable private targets. Therefore, we include $R \& D$, the ratio of $\mathrm{R} \& \mathrm{D}$ expenses divided by total assets in the fiscal year prior to the IPO date, and Growth, the sales growth rate from the year prior to the IPO to the IPO year as the proxies for growth in the regressions. All the financial information except for the industry valuation $P S_{\text {ind }}$ is for the fiscal year prior to the IPOs.

Megginson and Weiss (1991) find that venture capitalists provide a certification and monitoring role. We include a dummy variable $V C$ to indicate whether a firm is backed by venture capitalists. We follow Loughran and Ritter (2004) to include a dummy variable Top IB that equals one if the underwriter has a rank of 8 or higher. We use the updated Carter-Manaster Reputation ranking for IPO underwriter available at Jay Ritter's website (http://bear.warrington.ufl.edu/ritter/ipodata.htm). More information is available about the value of older firms. We also control for firm age (Age), measured as the number of years since founding, which is also provided by Jay Ritter's IPO data website. IPO markets are cyclical. We control for IPO market condition, measured as the average initial returns of IPOs within the same two-digit primary SIC industry code of the sample IPO between the firm's IPO filing date and its IPO date. We also use Proceeds, the number of shares sold in the offering multiplied by the offer price, to control for IPO size. Technology IPO firms experience higher first day returns (Loughran and Ritter (2004)). Accordingly, we include a Tech dummy variable, defined in 
Loughran and Ritter (2004). Underpricing is more prominent during the dot-com bubble period.

We include the dummy variable Bubble, which equals one if an IPO occurred in 1999 or 2000

and zero otherwise. Descriptive statistics are provided for these variables in Panel C of Table 1.

We also provide additional details about each variable's calculation in the Appendix.

\subsection{Sample characteristics}

IPOs with patents are firms with at least one patent granted in the five years before their IPO dates; IPOs without patents are firms with no patent granted during the same period. ${ }^{7}$ Panel A of Table 1 reports the year distribution of IPOs. Our sample spans periods of both hot and cold IPO markets. Overall, 19\% of IPOs have patents before offering. However, the proportion of IPOs with patents is lower at the beginning of our sample period $-17 \%$ in 1981 and approximately $13 \%$ for the period 1981-1989.

Panel B details the industry composition of the 4,795 sample IPOs. Based on the Song and Walking (1993) industry classification, our sample is well scattered across several industries; the Services industry exhibits some clustering with over $30 \%(1,448 / 4,795)$ of IPOs from that industry. The proportion of IPOs with patents varies significantly across industries; IPOs from technological industries such as Chemicals (including pharmaceutical and biotech firms with SIC of 28) (34\%), Machinery (41\%), and Instruments (48\%) are more likely to have patents before

\footnotetext{
7 There are 268 IPO firms that have received patent grants during their book building process. In unreported analyses, we find no significant impact of newly approved patents on final offer price, price revision, or underpricing. Information for pending patents is typically released via SEC filings and provides direct communication to prospective investors prior to IPOs. In addition, we also investigate the effect of patent applications filed during the book building process on IPO valuations. The NBER patent database only provides information on the patent application year, not the exact application date. We use the Harvard patent network Dataverse to obtain filing dates of patent applications. We then identify IPO firms that file patent applications during their book building process. We have 400 such IPOs; 253 of them receive patent grants in the five years before IPOs (IPOs with patents) and 147 IPOs do not receive any patent grant prior to IPOs (IPOs without patents).The unreported results show that for IPOs with patents, having patent applications filed during book building has no significant effect on IPO valuations. However, for IPOs without patents, there are significantly positive effects on expected valuation ratios and final valuation ratios.
} 
IPOs. To control for the effect of time and industry variations in our sample IPOs, we control for industry and year fixed-effects in regressions. Panel C compares issue and firm characteristics of IPOs with and without patents. IPOs with patents have a higher offer price and receive larger proceeds from offerings than IPOs without patents. IPOs with patents are more likely to be backed by VCs, to be underwritten by top-tier investment banks, and to be a high-tech company than IPOs without patents. Further, IPOs with patents are larger in total assets and sales. They invest more in $R \& D$ expenditures than IPOs without patents. However, IPOs with patents are less profitable and have lower leverage than IPOs without patents. Valuation ratios are skewed, and we report the median and the mean. Based on the median, IPOs with patents initially file for $\$ 4.39$ and receive $\$ 4.31$ for each dollar of sales, which is significantly higher than those for IPOs without patents at $\$ 2.56$ and $\$ 2.51$, respectively. There is no significant difference in price revisions or underpricing between IPOs with and without patents. Panel D reports patent information for IPOs with patents. On average, an IPO has 9.73 patents (2.14 scaled patents), receives 17.74 citations (6.3 scaled citations) up to the IPO date. On average, per $\$ 1$ million dollar of total assets, an IPO has 0.14 scaled patents and receives 0.36 scaled citations up to its IPO date.

\section{Empirical Results}

\subsection{IPO valuations: with patents vs. without patents}

We first examine the difference in IPO valuations of IPOs with and without patents to answer the question whether having a patent is valued in the primary market. We investigate four aspects of IPO valuations: Expected valuation ratio, the mid-point of the preliminary offer price range divided by sales per share for the fiscal year prior to the IPO date; Offer valuation ratio, 
final offer price divided by sales per share for the fiscal year prior to the IPO date; Price revisions, the percentage change from the initial offer price to the final offer price; and Initial returns, the percentage change from the final offer price to the market price at the end of first trading day. These four measures reflect how the primary market values IPOs with and without patents at different phases of initial public offerings. When a firm files for an IPO, its underwriters help it set an expected offer price range in the preliminary prospectus ( $\mathrm{S}-1$ form) filed with the SEC. Expected valuation ratio reflects how the underwriters value the IPO. Underwriters and the issuer then solicit information from investors during the roadshow. Based on the feedback from the book building process, they make adjustments on the initial offer price and set the final offer price on the night before IPO dates. Offer valuation ratio reflects how the IPO is valued by the primary market after incorporating information from the book building process, and Price revisions reflects the valuation adjustments made. Initial returns measure the difference between the valuation of the IPO in secondary market trading and the primary market.

Panel A of Table 2 reports the regressions of these four measures of IPO valuation for the full sample period. To test whether having patents before the IPO date incrementally affects the IPO valuations, we include several variables related to the IPO valuations. In Columns 1 and 2 , we estimate the following models for valuation ratios based on the expected offer prices and final offer prices, respectively:

$$
\begin{aligned}
& \text { Ln(Valuation ratio })_{i}=\beta_{0}+\beta_{1} \text { Patent }_{i}+\beta_{2} \text { PSind }_{i}+\beta_{3} \operatorname{Ln}\left(\text { Proceeds }_{i}+\beta_{4} \text { Prior industry-adjusted OPA }_{i}\right. \\
& \quad+\beta_{5} \text { Leverage }_{i}+\beta_{5} R \& D_{i}+\beta_{7} \text { Grwoth }_{i}+\beta_{8} V C_{i}+\beta_{9} \operatorname{Ln}(\text { Age })_{i} \\
& \\
& +\beta_{10} \text { Top IB }_{i}+\beta_{11} \text { Bubble }_{i}+\beta_{12} \text { Tech }_{i} \\
& \quad+\text { fixed effects }+\varepsilon_{i}
\end{aligned}
$$

The valuation ratio is the expected valuation ratio (offer valuation ratio) for column 1 (column 2). We use the log of valuation ratio to account for the high skewness of IPO valuation 
ratios. The dummy variable Patent is defined as one if an IPO firm has at least one patent granted in the five years before its IPO date and zero if an IPO firm has no patent granted during the same period. The coefficient estimates of other variables are consistent with the literature and are robust across Columns 1 and 2. For example, as shown in Bhojraj and Lee (2002) and Lian and Wang (2009), IPOs with lower leverage and/or from an industry with a higher valuation ratio tend to receive higher IPO valuations based on expected and final offer price. VC backing has a significant, positive effect on valuation ratios (Megginson and Weiss, 1991; Schultz, 1993; Brav and Gompers, 2003). IPOs with higher R\&D expenditures and/or faster sales growth receive higher valuation ratios (Kim and Ritter 1999, and Poulsen and Stegemoller 2008). Larger IPOs with a higher amount of proceeds raised receive lower valuation ratios. The estimated coefficients for Patent are positive and significant. Controlling for other factors, IPOs with patents are valued on average $13.6 \% / 12.6 \%$ higher at the initial filing/final offering than IPOs without patents. The primary market does incorporate the value of patents into the initial prices before IPO dates. Specifically, underwriters anticipate that investors will take notice of the positive information implied by having a patent and incorporate that into the offer price from the initial filing of the offering.

Column 3/4 reports the estimations of Price revisions/Initial returns regressions:

$$
\begin{aligned}
& \text { Price revisions/Initial returns } s_{i}=\beta_{0}+\beta_{1} \text { Patent }_{i}+\beta_{2} \operatorname{Ln}(\text { Proceeds })_{i}+\beta_{3} \text { Prior industry-adjusted OPA } A_{i} \\
& +\beta_{4} \text { Leverage }_{i}+\beta_{5} R \& D_{i}+\beta_{6} \text { Grwoth }_{i}+\beta_{7} V C_{i}+\beta_{8} \operatorname{Ln}(\text { Age })_{i} \\
& +\beta_{9} \text { Top IB }_{i}+\beta_{10} \text { Bubble }_{i}+\beta_{11} \text { Tech }_{i}+\beta_{12} \text { IPO } \text { market condition }_{i} / \text { Price revision }_{i} \\
& + \text { fixed effects }+\varepsilon_{i}
\end{aligned}
$$

Price revisions reflect the adjustments made by underwriters and issuers to incorporate the information revealed during book building (Beneniste and Spindt 1989). Therefore, if underwriters fully incorporate having a patent into the expected offer price at the initial filing, we 
would expect that IPOs with and without patents experience similar price revisions over the book building phase. If underwriters do not fully value having patents at the initial filing valuations, we should find the price revisions of IPOs with patents to be higher than IPOs without. To test this conjecture, we estimate a model of price revisions to control for other related factors similar to Dunbar and Forester (2008). ${ }^{8}$ The results are largely consistent with prior studies. For example, the coefficient estimates for Bubble and Tech dummy variables are both positive and significant. Most importantly, the coefficient for Patent dummy is negative but insignificant, suggesting that underwriters incorporate the information that the IPO firms have patents into the expected offer price and do not make further price adjustments for IPOs with patents.

IPOs with and without patents could have different Initial returns. The first day closing prices are likely upwardly biased estimates of true value due to the participation of sentimental investors who overpay for the IPOs (Ljungqvist, Nanda, and Singh, 2006, and Cook, Kieschnick, and VanNess, 2006). The first day closing prices are higher for IPOs with patents if investors are overoptimistic about the contribution of patents to IPO firms' future performance. Column 4 reports the estimations of Initial returns regression. The inferences on the control variables are generally consistent with the literature. Older IPOs have lower initial returns due to lower information asymmetry (e.g., Loughran and Ritter, 2004). Initial returns are positively related to price revisions, consistent with the partial adjustment relation between price discovery and information inducement (Hanley, 1993 and Johns and Ligon, 2009). Initial returns are more prominent during the dot-com bubble period as shown by the positive and significant coefficients of the Bubble dummy (e.g., Loughran and Ritter, 2004, Ljungqvist and Wilhelm, 2003).

\footnotetext{
${ }^{8}$ Dunbar and Forester (2008)'s regression model on price revisions is based on the literature on price adjustments (Bradley and Jordan, 2002; Benveniste, Ljungqvist, Wilhelm, and Yu, 2003; Loughran and Ritter, 2004; Lowry and Schwert, 2004).
} 
However, the coefficient for the Patent dummy is not significant. IPOs with patents are not underpriced more than IPOs without patents.

Hall, Jaffe, and Trejtenberg (2005) find that the link between citations/patents stocks and firm valuations for seasoned firms is stronger in the more recent time period. They suggest that changes in the patenting behavior of US firms during the mid-1980s due to the strengthening of patent rights and the sharp increase in the rate of patenting. To investigate whether there is similar time variation in the link between patent portfolios and IPO valuations, we split the sample into two sub-periods, 1981-1993 and 1994-2006 ${ }^{9}$. Panel B of Table 2 reports the regressions of IPO valuations for two sub-periods. It shows that markets and underwriters have improved their ability to value patents for newly public firms over time. In the early sub-period, IPOs with patents are valued on average $5.7 \% / 4.3 \%$ higher at the initial filing/final offering than IPOs without patents although insignificantly. In the later sub-period, IPOs with patents are valued on average $18.4 \% / 17.9 \%$ significantly higher at the initial filing/final offering than IPOs without patents.

\subsection{IPO valuations of IPOs with patents}

Given that IPOs with patents receive higher valuation than IPOs without patents, we focus on IPOs with patents to examine how the size and the quality of their patent portfolio at the time of offering are related to IPO valuations in this section. Specifically, we investigate how the number of patents, the citation count, and innovation efficiency described in section 2.2 are correlated with valuation ratios (Table 3) and initial returns (Table 4). The coefficients of other control variables are consistent with section 3.1 and previous studies; we focus on the coefficients of the number of patents, the citation count, and innovation efficiency in this section.

\footnotetext{
${ }^{9}$ We thank an anonymous referee for suggesting this analysis.
} 


\subsubsection{Final IPO valuations (offer prices)}

Panel A of Table 3 reports the results of regressions on IPO valuations based on offer prices to examine whether the size, quality of patent portfolios, and innovation efficiency are priced into the final IPO valuations of IPOs with patents. The model is similar to Eq. 1, with Patent dummy replaced by various patent metrics. We include Ln (Scaled Patent/Assets+1) to control only for the size of patent portfolios in column 1. In column 2, we include Ln (Scaled Citation/Assets+1) to control only for the quality of patent portfolios. The coefficients of both are significant at the $1 \%$ level. In column 3, we include Ln (Scaled Patent/Assets+1) and Ln (Scaled Citation/Assets+1) to control for the size and quality of patent portfolios. The coefficient of Ln (Scaled Citation/Assets+1) is still positive but no longer significant. The coefficient of Ln (Scaled Patent/Assets +1 ) is still significantly positive at 0.9 . The results suggest that the primary market incorporates the size but not the quality of IPOs' patent portfolios into the final offer price valuations of IPOs with patents. The effect of the size of patent portfolios on the offer price valuation ratio is also economically significant. For an IPO with median Scaled Patent/Assets at 0.029 (Table 1.D), a one standard deviation increase (0.616, Table 1.D)) in Scaled Patent/Assets is associated with the expected offer price to sales increasing by $42 \% .{ }^{10}$

Hirshleifer, Hsu, and Li (2012) document a positive relationship between innovative efficiency (patents or citations scaled by R\&D expenditures) and future stock returns. Similarly, we include number of patents scaled by $R \& D$ expenses in column 4 and citations scaled by $R \& D$ in column 5. The coefficient estimates for innovation efficiency based on number of patents and future citations are significant and positive. In column 6/7, we include Ln (Scaled Patent/Assets+1) and Ln (Innovation efficiency-Pat+1)/Ln (Innovation efficiency-Citation+1) to control for the size of patent portfolios and innovative efficiency. The coefficient for innovative

${ }^{10}[\ln (1+0.029+0.616)-\ln (1+0.029)]^{*} 0.90=0.42$ 
efficiency is still positive but no longer significant. The coefficient of Ln (Scaled Patent/Assets+1) is still significantly positive at $0.825 / 0.874$. In summary, we find that the number of patents, the citation count, and innovation efficiency (patents or citations scaled by research and development expenditure) are positively associated with offer price multiples but the effect of the number of patents subsumes that of the citation count/innovation efficiency.

Panels B and C of Table 3 report the results of regressions on IPO valuations for two subperiods. Similarly, it shows that the link between the size, quality of patent portfolios, and innovation efficiency and IPO valuations has strengthened over time. ${ }^{11}$

\subsubsection{Initial returns}

Table 4 reports the results of initial returns regressions (Eq. 2 with the Patent dummy replaced by various patent metrics), which estimate the effects of size, quality of the IPO's patent portfolios, and innovation efficiency on the valuation change for IPOs from the primary market to the secondary market. None of the coefficients of the size and quality of IPO's patent portfolios or innovation efficiency is significant, suggesting that underpricing is not related to the size, quality of the IPO's patent portfolios, or innovation efficiency.

Overall, the results on valuation ratios, price revisions, and initial returns suggest that: 1) information on having patents and the size of IPO patent portfolios are priced into IPO valuations from the beginning of the offering process, 2) information on having patents and the size of patent portfolios are uncorrelated with IPO underpricing.

\footnotetext{
11 The un-tabulated results on expected valuation ratios are similar to those in Table 3. The unreported results on price revisions for IPOs with patents show that size, quality of patent portfolio, and innovation efficiency are not significantly correlated with price revisions. Those results are consistent with Table 2, which shows that the size of the IPO's patent portfolio is priced into the IPO valuations from the beginning of the offering process.
} 


\subsection{The market value of newly public firms: Tobin's $Q$}

We use Tobin's $\mathrm{Q}$ as a proxy of a firm's valuation premium in this section to investigate the effects of the number of patents, the citation count, and innovation efficiency on IPO valuations. ${ }^{12}$ We use this proxy for several reasons. First, the extant literature on the patent valuation of seasoned public firms often uses Tobin's Q as a proxy of a firm's valuation premium. Second, using valuation ratios based on expected offer prices and offer prices, we show that having patents and/or larger patent portfolios has a significantly positive effect on IPO valuations in the primary market. Our results from valuation multiples in the primary market lead to the question of whether the positive effects that connect patent-related factors on Tobin's Q from secondary market valuation are present from the very beginning of IPO firms' public listing. To answer the question, we estimate models similar to those in Table 3 on Tobin's Q for each IPO in our sample at the first day of secondary market trading (TobinsQ_day1) and at the IPO's one-year anniversary (TobinsQ_year1). In addition, using final offer price, we also calculate Tobin's Q for each IPO at day 0 - the offer price (TobinsQ_day0) - as a second measure of an IPO's valuation in the primary market.

TobinQ_day0 is defined as the sum of the firm's market value of equity (offer price times the number of outstanding shares) and the book value of its total liabilities divided by the sum of the book value of its total assets and IPO proceeds. TobinQ_day1 is defined similarly except that we use the first trading day closing price to calculate the market value of equity. Book value of total assets and liabilities are for the fiscal year prior to IPO date. We follow Kim and Ritter (1999) and Hendricks and Miller (2014) by adding the amount of proceeds received from the IPO to the firm's most recently reported book value of assets prior to the offering. Hendricks and

\footnotetext{
12 We thank an anonymous referee for making the suggestion to analyze the effects of patents on Tobin's Q for newly public firms.
} 
Miller (2014) suggest that this calculation creates a more accurate representation of the assets being valued by investors at the beginning of the secondary market trading. TobinQ_year1 is defined as the sum of the firm's market value of equity (fiscal year end closing price times the number of outstanding shares) and the book value of its total liabilities divided by the book value of its total assets. The fiscal year end closing price and book value of total assets and liabilities are for the one fiscal year after IPO date.

Table 5 provides the results of Tobin's Q regressions. Panel A is for the Tobin's Q for each IPO at day 0 . We find that using Tobin's Q derived from offer prices, the effect of the number of patents, the citation count, and innovation efficiency on IPO valuation is always positive. For example, the coefficients of Ln (Scaled Patent/Assets+1) are significantly positive. This result suggests that the positive effect that connects the size of patent portfolios to Tobin's $\mathrm{Q}$ is present from the beginning of offerings for newly public IPOs. We also find that the positive effect of the size of patent portfolios on firms' Tobin's $Q$ is present from the first day of trading in the secondary market - the results of Panel B for Tobin's Q of each IPO at day 1 are consistent with those in Table 3, and the coefficients of Ln (Scaled Patent/Assets+1) are always significantly positive. Panel C for Tobin's Q of each IPO at the IPO's one-year anniversary shows results similar to those in Panel B.

\subsection{Innovation and long-run performance}

\subsubsection{Long-run stock performance}

IPOs with patents and/or with larger patent portfolios could receive higher IPO valuations but still be mispriced in the primary market. The primary market could overvalue innovation at IPOs if the market is too optimistic about the growth potential embedded in innovation. On the other hand, the IPO valuations for innovation may be inadequate if investors are unable to assess 
the prospects of innovation fully. In either case, the mis-valuation related to IPO patent portfolios should be reflected in long-run stock performance. In this section, we examine long-run stock performance to investigate whether the market values innovation appropriately at the IPOs.

To evaluate long-run stock performance, we calculate buy-and-hold abnormal return (BHAR) as following:

$$
\text { BHAR }_{i}=\prod_{t=1}^{\min (T, \text { delist })}\left(1+r_{i t}\right)-\prod_{t=1}^{\min (T, \text { delist })}\left(1+m r_{i t}\right)
$$

where $r_{a t}$ is the monthly return of IPO firm $i$ in calendar month $t\left(t=0\right.$ for IPO month), and $\mathrm{mr}_{\mathrm{it}}$ is the monthly return for the matched portfolio in calendar month $t$. $T$ is the $12 / 24 / 36^{\text {th }}$ months after IPO issuance or delisting, whichever comes first. That is, if IPO firms are delisted from CRSP before 12/24/36 months after issuance, we will calculate the IPO and its matched portfolio buyand-hold returns only up to the delisting month. For each IPO firm, we identify a size and bookto-market matched portfolio. We obtain 25 portfolios formed on size and book-to-market from Professor Kenneth R. French's website. ${ }^{13}$ French creates quintile breakpoints based on market value of equity (size) and ratios of book value of equity to market value of equity (book-tomarket) using only stocks trading on the NYSE. The market value of equity for each year $t$ is calculated at the end of June of year $t$. The book-to-market ratio for the June of year $t$ is the book value of equity for the last fiscal year end in t-1 divided by market value of equity for December of $\mathrm{t}-1$. The annual size breakpoints are then intersected with the book-to-market breakpoints to create 25 size and book-to-market portfolios using all NYSE, AMEX, and NASDAQ stocks for which they have data for market value of equity and (positive) book value of equity. We use an equally weighted return of all firms in a given portfolio. We then classify IPOs into these

\footnotetext{
${ }^{13}$ http://mba.tuck.dartmouth.edu/pages/faculty/ken.french/Data Library/tw 5 ports.html
} 
quintiles based on their market value of equity (offer price times number of outstanding shares) and book-to-market ratio (book value of equity for the fiscal year prior to IPOs divided by the market value of equity based on offer price). The corresponding portfolio is the IPO firm's size and book-to-market matched portfolio.

Panel A of Table 6 presents the regression results of the relation between the size and the quality of patent portfolios and BHAR - buy-and-hold cumulative abnormal returns - from one to three years after the IPO offerings for IPOs with patents. The results are largely consistent with prior studies. For example, one to three year abnormal buy-and-hold returns are positively related to the investment banker reputation (Carter, Dark, and Sapp, 2010). IPOs offered in the dot-com bubble period generally have lower abnormal long-term stock returns, suggesting that IPOs offered in the "hot" market tend to underperform (Derrien, 2005). Most importantly, the size and quality of IPOs' patent portfolios are not significantly related to long-run stock returns. We find no evidence that IPOs' patent portfolios are associated with abnormal post-IPO long-run stock returns, suggesting that IPOs with larger patent portfolios are not overvalued in the primary market, leading to no abnormal long-run stock performance in the secondary equity market than IPOs with smaller patent portfolios.

\subsubsection{Long-run operating performance}

We further investigate the effect of IPOs' patent portfolios on post-IPO abnormal operating performance up to three years after IPOs. IPOs with larger patent portfolios could receive higher IPO valuations because investors view those IPOs as safer due to their patent portfolios or because investors perceive that those IPOs will have better operating performance and, therefore, generate more cash flows for investors. If the premium is due to the perceived lower risk, we should expect that IPOs with larger patent portfolios have similar or worse post- 
IPO long-run operating performance. Otherwise, IPOs with larger patent portfolios should have better post-IPO long-run operating performance.

Panel B of Table 6 reports the regression results for post-IPO operating performance (measured as industry-adjusted OPA) for IPOs with patents. Several control variables at IPO appear to be significantly related to post-IPO operating performance. For example, operating performance is related to firm age as older IPOs tend to have better OPA. One to three year abnormal operating performances are positively related to the investment banker reputation (Dong, Michel, and Pandes, 2011). We do not find significance in any of the coefficients for the size and the quality of IPOs' patent portfolios.

Overall, results on long-run stock and operating performances suggest that the amount of the offer valuation premium of IPOs with larger patent portfolios is appropriate. For IPOs with patents, this premium is likely a response to the perceived lower risk due to larger patent portfolios with diversified patents and is not related to higher post-IPO performance expectations.

\section{Conclusions}

In this paper, we investigate an important yet understudied aspect of IPOs, namely, the IPO valuations associated with innovation. Using patent metrics as measures of innovation capabilities, we investigate whether and how the primary market values the innovations of newly public firms at their IPOs by examining the link between the size, quality, and innovation efficiency of their patent portfolios and IPO valuations. We find that the number of patents, the citation count, and innovation efficiency are positively associated with offer price multiples but the effect of the number of patents subsumes that of the citation count and innovation efficiency. 
The size, the quality, and innovation efficiency of an IPO's patent portfolio have no significant effect on price revisions or IPO first-day returns, suggesting markets do not significantly undervalue the patent portfolio in the initial offer price. We obtain no evidence that an IPO's patent portfolio is overvalued in the primary market, as the number of patents and the citation count are not significantly associated with long-run stock returns or long-run operating performance. 


\section{References}

Barnanchu, N., R. Kieschnick, and R. Moussawi, 2014, Motivating Innovation in Newly Public Firms, Journal of Financial Economics 111, 578-588.

Bena, Jan. and Kai Li, 2014, Corporate Innovations and Mergers and Acquisitions, Journal of Finance 69, 1923-1960.

Benveniste, L., A. Ljungqvist, W. Wilhelm, and X. Yu, 2003, Evidence of Information Spillovers in the Production of Investment Banking Services, Journal of Finance 58, 577-608.

Bernstein, Shai, 2015, Does going public affect innovation? Journal of Finance 70, 1365-1403.

Bessler, Wolfgang, and Claudia Bittelmeyer, 2008, Patents and the performance of technology firms: Evidence from initial public offerings in Germany, Financial Markets and Portfolio Management 22, 323-356.

Bhojraj, Sanjeev, and Charles M. C. Lee, 2002, Who is my peer? A valuation-based approach to the selection of comparable firms, Journal of Accounting Research 40, 407-439.

Bradley, D. and B. Jordan, 2002, Partial Adjustment to Public Information and IPO Underpricing, Journal of Financial and Quantitative Analysis 37, 595-616.

Brown, James R., Steven M. Fazzari, and Bruce C. Petersen, 2009, Financing innovation and growth: Cash flow, external equity, and the 1990s R\&D boom, Journal of Finance 64, 151-185.

Carter, Richard B., Frederick H. Dark, and Ajai K. Singh, 1998, Underwriter reputation, initial returns, and the long-run performance of IPO stocks, Journal of Finance 53, 285-311.

Carter, R.B., F.H. Dark, and T. Sapp, 2010, Underwriter reputation and IPO issuer alignment 1981-2005, Quarterly Review of Economics and Finance 50, 443-455.

Chemmanur, Thomas J., and Imants Paeglis, 2005, Management quality, certification, and initial public offerings, Journal of Financial Economics 76, 331-368.

Cohen, Lauren, Karl Diether, and Christopher Malloy, 2013, Misvaluing innovation, Review of Financial Studies 26, 635-666.

Cook, D.O., R. Kieschnick, and R.A. Van Ness, 2006, On the Marketing of IPO, Journal of Financial Economics 82, 35-61.

Daniel, Kent, and Sheridan Titman, 2006, Market reactions to tangible and intangible information, Journal of Finance 61, 1605-1643.

Derrien, F., 2005, IPO Pricing in "Hot" Market Conditions: Who Leaves Money on the Table, Journal of Finance, 60, 487-521. 
Dong, M., J. Michel, and J.A. Pandes, 2011, Underwriter Quality and Long Run IPO Performance, Financial Management 40, 219-251.

Dunbar, C., Foerster, S., 2008, Second time lucky? Withdrawn IPOs that return to the market. Journal of Financial Economics 87, 610-635.

Ferreira, Daniel, Gustavo Manso, and André C. Silva, 2014, Incentives to innovate and the decision to go public or private, Review of Financial Studies 27, 256-300.

Gu, Feng, 2005, Innovation, future earnings, and market efficiency, Journal of Accounting Auditing and Finance 20, 385-418.

Guo, Re-Jin, Baruch Lev, and Charles Shi, 2006, Explaining the short- and long-term IPO anomalies in the US by R\&D, Journal of Business Finance \& Accounting 33, 550-579.

Guo, Re-Jin, Baruch Lev, and Nan Zhou, 2005, The valuation of biotech IPOs, Journal of Accounting, Auditing \& Finance 20, 423-459.

Hall, Bronwyn Hughes, Adam Jaffe, and Manuel Trajtenberg, 2001, The NBER patent citations data file: Lessons, insights and methodological tools, NBER working paper series.

Hall, Bronwyn H., Adam Jaffe, and Manuel Trajtenberg, 2005, Market value and patent citations, The RAND Journal of Economics 36, 16-38.

Hanley, K.W., 1993, The Underpricing of Initial Public Offerings and the Partial Adjustment Phenomenon, Journal of Financial Economics 34, 231-250.

Heeley, Michael B., Sharon F. Matusik, and Neelam Jain, 2007, Innovation, appropriability, and the underpricing of initial public offerings, Academy of Management Journal 50, 209-225.

Hendricks, Bradley E., and Gregory S. Miller, 2014, Does the Founder's Premium Really Exist? Evidence from a Longitudinal Study of IPO Firms, Working paper, University of Michigan.

Hirshleifer, David, Po-Hsuan Hsu, and Dongmei Li, 2013, Innovative efficiency and stock returns, Journal of Financial Economics 107, 632-654.

Jensen, Michael C., 1993, The modern industrial revolution, exit, and the failure of internal control systems, Journal of Finance 48, 831-880.

Johns T.L. and J.A. Ligon, 2009, The day of the week effect in IPO initial returns, Quarterly Review of Economics and Finance 49, 110-127.

Kim, M. and J. Ritter, 1999, Valuing IPOs, Journal of Financial Economics 53, 409-437. 
Lerner, Josh, Morten Sorensen, and P. E. R. StrÖMberg, 2011, Private equity and long-run investment: The case of innovation, Journal of Finance 66, 445-477.

Ljungqvist, A., V. Nanda, and R. Singh, 2006, Hot Markets, Investor Sentiment, and IPO Pricing, Journal of Business 79, 1667-1702.

Ljungqvist, A. and W. Wilhelm, 2003, IPO Pricing in the Dot-com Bubble, Journal of Finance $58,723-752$.

Loughran, Tim, and Jay R. Ritter, 1995, The new issues puzzle, Journal of Finance 50, 23-51.

Loughran, T. and J. Ritter, 2004, Why Has IPO Underpricing Changed Over Time? Financial Management 33, 5-37.

Lowry, M. and W. Schwert, 2004, Is the IPO Pricing Process Efficient? Journal of Financial Economics 71, 3-26.

Matolcsy, Zoltan P., and Anne Wyatt, 2008, The Association between Technological Conditions and the Market Value of Equity, Accounting Review 83, 479-518.

Megginson, William L., and Kathleen A. Weiss, 1991, Venture capitalist certification in initial public offerings, Journal of Finance 46, 879-903.

Pástor, Luboš, Lucian A. Taylor, and Pietro Veronesi, 2009, Entrepreneurial learning, the IPO decision, and the post-IPO drop in firm profitability, Review of Financial Studies 22, 3005-3046.

Poulsen, A., Stegemoller, M., 2008, Moving from private to public ownership: Selling out to public firms vs. initial public offerings, Financial Management 37, 81-101.

Purnanandam, Amiyatosh K., and Bhaskaran Swaminathan, 2004, Are IPOs really underpriced? Review of Financial Studies 17, 811-848.

Ritter, Jay R., 1991, The long-run performance of initial public offerings, Journal of Finance 46, 3-27.

Tian, Xuan, and Tracy Yue Wang, 2014, Tolerance for failure and corporate innovation, Review of Financial Studies 27, 211-255. 


\section{Table 1}

\section{Sample distribution}

This table reports the summary statistics of the key variables in the analysis. IPOs with patents are firms that are granted at least one patent in the 5 years before their IPO dates. IPOs without patents are firms that do not receive any patent grant during the same period. Panel A (B) shows the year (industry) distribution of IPO firms. The year is defined with offering dates. The industry classification is defined with the first 2-digit primary SIC code following Song and Walking (1993). Panel C compares issue and firm characteristics for IPOs with and without patents. Pvalue of mean difference is for the two-tailed t-test. P-value of median difference is for the two-tailed Wilcoxon rank-sum test. Panel D shows the patent information in the five years up to the IPO date for IPOs with patents. All variables are defined in the Appendix.

\begin{tabular}{|c|c|c|c|c|}
\hline \multicolumn{5}{|c|}{ Panel A. Year distribution } \\
\hline \multirow[b]{2}{*}{ Year } & \multicolumn{2}{|c|}{ \# of IPOs } & \multirow[b]{2}{*}{$\begin{array}{l}(3) \\
\text { All }\end{array}$} & \multirow{2}{*}{$\begin{array}{c}(1) /(3 \\
\%\end{array}$} \\
\hline & $\begin{array}{l}\text { (1) With } \\
\text { patents }\end{array}$ & $\begin{array}{l}\text { (2) Without } \\
\text { patents }\end{array}$ & & \\
\hline 1981 & 23 & 112 & 135 & 17 \\
\hline 1982 & 4 & 53 & 57 & 7 \\
\hline 1983 & 45 & 259 & 304 & 15 \\
\hline 1984 & 14 & 122 & 136 & 10 \\
\hline 1985 & 14 & 126 & 140 & 10 \\
\hline 1986 & 35 & 228 & 263 & 13 \\
\hline 1987 & 30 & 174 & 204 & 15 \\
\hline 1988 & 13 & 71 & 84 & 15 \\
\hline 1989 & 15 & 65 & 80 & 19 \\
\hline 1990 & 11 & 66 & 77 & 14 \\
\hline 1991 & 39 & 152 & 191 & 20 \\
\hline 1992 & 61 & 201 & 262 & 23 \\
\hline 1993 & 70 & 270 & 340 & 21 \\
\hline 1994 & 52 & 219 & 271 & 19 \\
\hline 1995 & 68 & 226 & 294 & 23 \\
\hline 1996 & 82 & 351 & 433 & 19 \\
\hline 1997 & 57 & 218 & 275 & 21 \\
\hline 1998 & 24 & 126 & 150 & 16 \\
\hline 1999 & 50 & 279 & 329 & 15 \\
\hline 2000 & 76 & 185 & 261 & 29 \\
\hline 2001 & 13 & 36 & 49 & 27 \\
\hline 2002 & 7 & 41 & 48 & 15 \\
\hline 2003 & 10 & 35 & 45 & 22 \\
\hline 2004 & 51 & 82 & 133 & 38 \\
\hline 2005 & 23 & 89 & 112 & 21 \\
\hline 2006 & 35 & 87 & 122 & 29 \\
\hline Total & 922 & 3,873 & 4,795 & 19 \\
\hline
\end{tabular}




\begin{tabular}{lcccc}
\hline Panel B. Industry Distribution & \multicolumn{3}{c}{} \\
\cline { 2 - 4 } & \multicolumn{3}{c}{ \# of IPOs } & \\
\cline { 2 - 4 } & With & Without & $(3)$ & $(1) /(3)$ \\
Industry (SIC2 codes) & patents & patents & All & $\%$ \\
\hline Agriculture (01-09) & 5 & 14 & 19 & 26 \\
Mining (10-14) & 1 & 123 & 124 & 1 \\
Construction (15-19) & 3 & 47 & 50 & 6 \\
Food and tobacco (20-21) & 10 & 75 & 85 & 12 \\
Textiles and apparel (22-23) & 6 & 64 & 70 & 9 \\
Lumber, furniture, paper, and print (24-27) & 13 & 90 & 103 & 13 \\
Chemicals (28) & 124 & 244 & 368 & 34 \\
Petroleum, rubber, and plastics (29-30) & 9 & 40 & 49 & 18 \\
Leather, stone, glass (31-32) & 10 & 19 & 29 & 34 \\
Primary and fabricated metals (33-34) & 29 & 80 & 109 & 27 \\
Machinery (35-36) & 308 & 450 & 758 & 41 \\
Transport equipment (37) & 26 & 53 & 79 & 33 \\
Instruments and miscellaneous manufacturing (38-39) & 207 & 221 & 428 & 48 \\
Transport, communications, utilities (40-49) & 20 & 377 & 397 & 5 \\
Wholesale trade (50-51) & 10 & 178 & 188 & 5 \\
Retail trade (52-59) & 11 & 441 & 452 & 2 \\
Hotels and personal services (70-71) & 0 & 38 & 38 & 0 \\
Services (72-89) & 130 & 1,318 & 1,448 & 9 \\
Public administration and others (90-99) & 0 & 1 & 1 & 0 \\
Total & 922 & 3,873 & 4,795 & 19 \\
\hline
\end{tabular}




\begin{tabular}{|c|c|c|c|c|}
\hline \multicolumn{5}{|c|}{ Panel C: Issue and firm characteristics } \\
\hline & \multicolumn{3}{|c|}{ Mean } & \multirow[b]{2}{*}{$\begin{array}{c}\text { Sample } \\
\text { size }\end{array}$} \\
\hline & $\begin{array}{l}\text { With } \\
\text { patents }\end{array}$ & $\begin{array}{l}\text { Without } \\
\text { patents }\end{array}$ & $\begin{array}{c}\mathrm{p}- \\
\text { value }\end{array}$ & \\
\hline \multicolumn{5}{|l|}{ Issue characteristics } \\
\hline$\overline{\text { Expected offer price }}$ & 12.68 & 11.85 & 0.00 & $914 / 3,841$ \\
\hline Offer price & 12.57 & 11.92 & 0.00 & $922 / 3,873$ \\
\hline Gross proceeds (\$m) & 76 & 59 & 0.01 & $922 / 3,873$ \\
\hline VC & 0.62 & 0.37 & 0.00 & $922 / 3,873$ \\
\hline Age & 16 & 15 & 0.19 & $919 / 3,801$ \\
\hline Underwriter's rank & 7.50 & 7.03 & 0.00 & $904 / 3,805$ \\
\hline Top tier underwriter & 0.69 & 0.59 & 0.00 & $922 / 3,873$ \\
\hline Bubble & 0.14 & 0.12 & 0.16 & $922 / 3,873$ \\
\hline Tech & 0.52 & 0.31 & 0.00 & $922 / 3,873$ \\
\hline IPO market condition & 0.21 & 0.23 & 0.74 & $922 / 3,873$ \\
\hline \multicolumn{5}{|l|}{ Firm characteristics } \\
\hline Assets & 265 & 160 & 0.02 & $892 / 3,588$ \\
\hline Sales & 246 & 169 & 0.04 & $886 / 3,540$ \\
\hline Prior Industry-adjusted OPA & -0.22 & -0.11 & 0.00 & $884 / 3,528$ \\
\hline Leverage & 0.33 & 0.39 & 0.00 & $892 / 3,588$ \\
\hline $\mathrm{R} \& \mathrm{D}$ & 0.25 & 0.12 & 0.00 & $922 / 3,873$ \\
\hline Sales growth & 1.49 & 4.28 & 0.43 & $841 / 3,450$ \\
\hline \multicolumn{5}{|l|}{ Valuation } \\
\hline Expected valuation ratio: $\mathrm{P} / \mathrm{S}$ & 122 & 99 & 0.66 & $835 / 3,426$ \\
\hline median & 4.39 & 2.56 & 0.00 & $835 / 3,426$ \\
\hline Valuation ratio: $\mathrm{P} / \mathrm{S}$ & 122 & 90 & 0.51 & $842 / 3,453$ \\
\hline median & 4.31 & 2.51 & 0.00 & $842 / 3,453$ \\
\hline Price revisions & 0.00 & 0.01 & 0.22 & $914 / 3,841$ \\
\hline Initial returns & 0.21 & 0.20 & 0.83 & $922 / 3,873$ \\
\hline
\end{tabular}

\begin{tabular}{lcccccc}
\hline Panel D: Patent information & & & & & & \\
\hline Variable & $25 \%$ & Median & Mean & $75 \%$ & SD & $\mathrm{N}$ \\
\hline Number of patents & 1.000 & 3.000 & 9.728 & 7.000 & 34.591 & 922 \\
Number of citations & 0.000 & 3.000 & 17.741 & 11.000 & 59.325 & 922 \\
Scaled Patent & 0.234 & 0.624 & 2.139 & 1.701 & 8.218 & 922 \\
Scaled Citation & 0.000 & 1.254 & 6.301 & 4.512 & 19.971 & 922 \\
Scaled Patent /Assets & 0.007 & 0.029 & 0.139 & 0.090 & 0.616 & 892 \\
Scaled Citation /Assets & 0.000 & 0.046 & 0.364 & 0.225 & 1.097 & 892 \\
\hline
\end{tabular}


Table 2

\section{IPO valuations: Patent vs. No Patent}

Panel A/B/C shows estimates of OLS regressions of IPO valuation for the full sample period 1981-2006/for the subperiod 1981-1993/for the sub-period 1994-2006. The dependent variables are valuation measures at different IPO stages. The expected valuation ratios (offer valuation ratio) are defined as expected offer price (offer price) divided by sales per share from the fiscal year preceding the IPO date. The expected offer price is the midpoint of the initial price range. Price revision is the offer price divided by the midpoint of the initial filing price range minus one. Initial return is the closing price on the first trading day divided by the offer price minus one. Robust $t$-statistics are reported in parentheses below coefficient estimates. We control for industry (based on the 2-digit primary SIC code) and year (based on IPO date) fixed effects. The superscripts ***,**,* denote statistical significance at the $1 \%, 5 \%$ and $10 \%$ level, respectively, in two-tailed tests. All variables are defined in the Appendix.

\begin{tabular}{|c|c|c|c|c|}
\hline \multicolumn{5}{|c|}{ Panel A: Full Sample Period: $1981-2006$} \\
\hline \multirow[b]{3}{*}{ Explanatory variables } & \multicolumn{4}{|c|}{ Dependent variables } \\
\hline & (1) & $(2)$ & (3) & (4) \\
\hline & $\begin{array}{l}\text { Expected valuation } \\
\text { ratio: } \operatorname{Ln}(\mathrm{P} / \mathrm{S})\end{array}$ & $\begin{array}{l}\text { Offer valuation } \\
\text { ratio: } \operatorname{Ln}(\mathrm{P} / \mathrm{S})\end{array}$ & $\begin{array}{l}\text { Price } \\
\text { revisions }\end{array}$ & Initial returns \\
\hline Patent & $\begin{array}{l}0.136 * * * \\
(2.673)\end{array}$ & $\begin{array}{l}0.126^{* * *} \\
(2.429)\end{array}$ & $\begin{array}{l}-0.012 \\
(-1.288)\end{array}$ & $\begin{array}{l}-0.001 \\
(-0.046)\end{array}$ \\
\hline $\mathrm{PS}_{\mathrm{ind}}$ & $\begin{array}{l}0.194 * * * \\
(4.669)\end{array}$ & $\begin{array}{l}0.183 * * * \\
(4.446)\end{array}$ & & \\
\hline Ln(Proceeds) & $\begin{array}{l}-0.134 * * * \\
(-5.552)\end{array}$ & $\begin{array}{l}-0.068 * * * \\
(-2.743)\end{array}$ & $\begin{array}{l}0.064 * * * \\
(11.860)\end{array}$ & $\begin{array}{l}-0.031 * * * \\
(-3.302)\end{array}$ \\
\hline $\begin{array}{l}\text { Prior industry-adjusted } \\
\text { OPA }\end{array}$ & $\begin{array}{l}-1.314 * * * \\
(-9.290)\end{array}$ & $\begin{array}{l}-1.293 * * * \\
(-8.929)\end{array}$ & $\begin{array}{l}0.021 \\
(0.956)\end{array}$ & $\begin{array}{l}-0.022 \\
(-0.642)\end{array}$ \\
\hline Leverage & $\begin{array}{l}-0.006 \\
(-0.089)\end{array}$ & $\begin{array}{l}-0.042 \\
(-0.584)\end{array}$ & $\begin{array}{l}-0.044 * * * \\
(-4.300)\end{array}$ & $\begin{array}{l}-0.046 * * * \\
(-2.778)\end{array}$ \\
\hline $\mathrm{R} \& \mathrm{D}$ & $\begin{array}{l}0.491 * * \\
(2.091)\end{array}$ & $\begin{array}{l}0.473 * * \\
(1.972)\end{array}$ & $\begin{array}{l}0.038 \\
(1.247)\end{array}$ & $\begin{array}{l}0.001 \\
(0.027)\end{array}$ \\
\hline Growth & $\begin{array}{l}0.252 * * * \\
(24.008)\end{array}$ & $\begin{array}{l}0.255^{* * * *} \\
(24.097)\end{array}$ & $\begin{array}{l}0.004 * \\
(1.935)\end{array}$ & $\begin{array}{l}0.015^{* * *} \\
(4.081)\end{array}$ \\
\hline $\mathrm{VC}$ & $\begin{array}{l}0.348 * * * \\
(7.948)\end{array}$ & $\begin{array}{l}0.349 * * * \\
(7.833)\end{array}$ & $\begin{array}{l}0.004 \\
(0.511)\end{array}$ & $\begin{array}{l}0.016 \\
(1.252)\end{array}$ \\
\hline Ln(Age $)$ & $\begin{array}{l}-0.365^{* * * *} \\
(-18.256)\end{array}$ & $\begin{array}{l}-0.388 * * * \\
(-18.705)\end{array}$ & $\begin{array}{l}-0.021 * * * \\
(-5.401)\end{array}$ & $\begin{array}{l}-0.010^{*} \\
(-1.740)\end{array}$ \\
\hline Top IB & $\begin{array}{l}0.037 \\
(0.817)\end{array}$ & $\begin{array}{l}0.001 \\
(0.021)\end{array}$ & $\begin{array}{l}-0.028 * * * \\
(-3.601)\end{array}$ & $\begin{array}{l}0.018 \\
(1.459)\end{array}$ \\
\hline Bubble & $\begin{array}{l}1.225^{* * *} \\
(7.998)\end{array}$ & $\begin{array}{l}1.208^{* * *} \\
(8.119)\end{array}$ & $\begin{array}{l}-0.006 \\
(-0.196)\end{array}$ & $\begin{array}{l}0.383^{* * *} \\
(9.447)\end{array}$ \\
\hline Tech & $\begin{array}{l}0.167 * * * \\
(2.638)\end{array}$ & $\begin{array}{l}0.203 * * * \\
(3.170)\end{array}$ & $\begin{array}{l}0.027 * * \\
(2.231)\end{array}$ & $\begin{array}{l}0.010 \\
(0.428)\end{array}$ \\
\hline IPO market condition & & & $\begin{array}{l}0.004 \\
(1.268)\end{array}$ & $\begin{array}{l}0.002 \\
(0.689)\end{array}$ \\
\hline Price revision & & & & $\begin{array}{l}0.925 * * * \\
(10.404)\end{array}$ \\
\hline Constant & $\begin{array}{l}1.536 * * * \\
(3.634)\end{array}$ & $\begin{array}{l}1.332 * * * \\
(2.851)\end{array}$ & $\begin{array}{l}-0.212 * * * \\
(-2.765)\end{array}$ & $\begin{array}{l}0.122 * * \\
(2.382)\end{array}$ \\
\hline Industry and Year FE & Yes & Yes & Yes & Yes \\
\hline Observations & 4197 & 4228 & 4198 & 4198 \\
\hline Adjusted R-squared & 0.662 & 0.659 & 0.185 & 0.447 \\
\hline
\end{tabular}




\begin{tabular}{|c|c|c|c|c|c|c|c|c|}
\hline \multicolumn{9}{|c|}{ Panel B: Subsample period } \\
\hline \multirow[b]{4}{*}{ Explanatory variables } & \multicolumn{4}{|c|}{ Period: 1981-1993 } & \multicolumn{4}{|c|}{ Period: 1994-2006 } \\
\hline & \multicolumn{4}{|c|}{ Dependent variables } & \multicolumn{4}{|c|}{ Dependent variables } \\
\hline & (1) & $(2) \times$ & $(3)$ & (4) & (1) & $(2)$ & (3) & (4) \\
\hline & $\begin{array}{l}\text { Expected } \\
\text { valuation } \\
\text { ratio: } \mathrm{Ln}(\mathrm{P} / \mathrm{S})\end{array}$ & $\begin{array}{l}\text { Offer } \\
\text { valuation } \\
\text { ratio: } \\
\mathrm{Ln}(\mathrm{P} / \mathrm{S})\end{array}$ & $\begin{array}{l}\text { Price } \\
\text { revisions }\end{array}$ & $\begin{array}{l}\text { Initial } \\
\text { returns }\end{array}$ & $\begin{array}{l}\text { Expected } \\
\text { valuation } \\
\text { ratio: } \operatorname{Ln}(\mathrm{P} / \mathrm{S}) \\
\end{array}$ & $\begin{array}{l}\text { Offer } \\
\text { valuation } \\
\text { ratio: } \\
\mathrm{Ln}(\mathrm{P} / \mathrm{S}) \\
\end{array}$ & $\begin{array}{l}\text { Price } \\
\text { revisions }\end{array}$ & $\begin{array}{l}\text { Initial } \\
\text { returns }\end{array}$ \\
\hline Patent & $\begin{array}{l}0.057 \\
(0.814)\end{array}$ & $\begin{array}{l}0.043 \\
(0.616)\end{array}$ & $\begin{array}{l}-0.014 \\
(-1.326)\end{array}$ & $\begin{array}{l}0.000 \\
(0.011)\end{array}$ & $\begin{array}{l}0.184 * * * \\
(2.651)\end{array}$ & $\begin{array}{l}0.179 * * \\
(2.538)\end{array}$ & $\begin{array}{l}-0.009 \\
(-0.666)\end{array}$ & $\begin{array}{l}-0.002 \\
(-0.081)\end{array}$ \\
\hline $\mathrm{PS}_{\text {ind }}$ & $\begin{array}{l}0.432 * * * \\
(3.946)\end{array}$ & $\begin{array}{l}0.422 * * * \\
(4.008)\end{array}$ & & & $\begin{array}{l}0.207 * * * \\
(3.642)\end{array}$ & $\begin{array}{l}0.202 * * * \\
(3.536)\end{array}$ & & \\
\hline $\operatorname{Ln}($ Proceeds $)$ & $\begin{array}{l}-0.046 \\
(-1.482)\end{array}$ & $\begin{array}{l}0.003 \\
(0.101)\end{array}$ & $\begin{array}{l}0.041 * * * \\
(8.374)\end{array}$ & $\begin{array}{l}-0.016 * * * \\
(-3.210)\end{array}$ & $\begin{array}{l}-0.190 * * * \\
(-5.439)\end{array}$ & $\begin{array}{l}-0.104 * * * \\
(-2.907)\end{array}$ & $\begin{array}{l}0.088 * * * \\
(9.028)\end{array}$ & $\begin{array}{l}-0.033^{*} \\
(-1.768)\end{array}$ \\
\hline $\begin{array}{l}\text { Prior industry-adjusted } \\
\text { OPA }\end{array}$ & $\begin{array}{l}-0.891 * * * \\
(-4.844)\end{array}$ & $\begin{array}{l}-0.822 * * * \\
(-4.441)\end{array}$ & $\begin{array}{l}0.074 * * * \\
(2.702)\end{array}$ & $\begin{array}{l}0.029 \\
(0.925)\end{array}$ & $\begin{array}{l}-1.378 * * * \\
(-6.996)\end{array}$ & $\begin{array}{l}-1.365 * * * \\
(-6.735)\end{array}$ & $\begin{array}{l}0.004 \\
(0.130)\end{array}$ & $\begin{array}{l}-0.010 \\
(-0.166)\end{array}$ \\
\hline Leverage & $\begin{array}{l}-0.057 \\
(-0.527)\end{array}$ & $\begin{array}{l}-0.080 \\
(-0.740)\end{array}$ & $\begin{array}{l}-0.027 * * \\
(-2.176)\end{array}$ & $\begin{array}{l}-0.017 \\
(-1.357)\end{array}$ & $\begin{array}{l}-0.013 \\
(-0.147)\end{array}$ & $\begin{array}{l}-0.055 \\
(-0.636)\end{array}$ & $\begin{array}{l}-0.053 * * * \\
(-3.686)\end{array}$ & $\begin{array}{l}-0.060 * * \\
(-2.398)\end{array}$ \\
\hline $\mathrm{R} \& \mathrm{D}$ & $\begin{array}{l}1.731 * * * \\
(7.457)\end{array}$ & $\begin{array}{l}1.751 * * * \\
(7.485)\end{array}$ & $\begin{array}{l}0.028 \\
(1.280)\end{array}$ & $\begin{array}{l}-0.001 \\
(-0.059)\end{array}$ & $\begin{array}{l}0.360 * * \\
(2.343)\end{array}$ & $\begin{array}{l}0.339 * * \\
(2.188)\end{array}$ & $\begin{array}{l}0.040 \\
(0.867)\end{array}$ & $\begin{array}{l}0.006 \\
(0.112)\end{array}$ \\
\hline Growth & $\begin{array}{l}0.241 * * * \\
(9.718)\end{array}$ & $\begin{array}{l}0.242 * * * \\
(9.660)\end{array}$ & $\begin{array}{l}0.001 \\
(0.839)\end{array}$ & $\begin{array}{l}0.002 \\
(0.928)\end{array}$ & $\begin{array}{l}0.249 * * * \\
(22.102)\end{array}$ & $\begin{array}{l}0.252 * * * \\
(22.165)\end{array}$ & $\begin{array}{l}0.004^{*} \\
(1.775)\end{array}$ & $\begin{array}{l}0.017 * * * \\
(3.994)\end{array}$ \\
\hline $\mathrm{VC}$ & $\begin{array}{l}0.192 * * * \\
(3.697)\end{array}$ & $\begin{array}{l}0.175^{* * *} \\
(3.293)\end{array}$ & $\begin{array}{l}-0.006 \\
(-0.687)\end{array}$ & $\begin{array}{l}-0.003 \\
(-0.320)\end{array}$ & $\begin{array}{l}0.399 * * * \\
(6.507)\end{array}$ & $\begin{array}{l}0.418 * * * \\
(6.718)\end{array}$ & $\begin{array}{l}0.022 \\
(1.517)\end{array}$ & $\begin{array}{l}0.033 \\
(1.338)\end{array}$ \\
\hline Ln(Age) & $\begin{array}{l}-0.344 * * * \\
(-12.649)\end{array}$ & $\begin{array}{l}-0.361 * * * \\
(-12.899)\end{array}$ & $\begin{array}{l}-0.015 * * * \\
(-3.581)\end{array}$ & $\begin{array}{l}-0.013 * * * \\
(-3.169)\end{array}$ & $\begin{array}{l}-0.366 * * * \\
(-12.163)\end{array}$ & $\begin{array}{l}-0.396 * * * \\
(-12.696)\end{array}$ & $\begin{array}{l}-0.028 * * * \\
(-4.294)\end{array}$ & $\begin{array}{l}-0.013 \\
(-1.156)\end{array}$ \\
\hline Top IB & $\begin{array}{l}-0.028 \\
(-0.497)\end{array}$ & $\begin{array}{l}-0.072 \\
(-1.266)\end{array}$ & $\begin{array}{l}-0.032 * * * \\
(-3.458)\end{array}$ & $\begin{array}{l}-0.011 \\
(-1.387)\end{array}$ & $\begin{array}{l}0.054 \\
(0.791)\end{array}$ & $\begin{array}{l}0.022 \\
(0.324)\end{array}$ & $\begin{array}{l}-0.028 * * \\
(-2.241)\end{array}$ & $\begin{array}{l}0.027 \\
(1.193)\end{array}$ \\
\hline Bubble & & & & & $\begin{array}{l}1.431 * * * \\
(12.688)\end{array}$ & $\begin{array}{l}1.425 * * * \\
(12.320)\end{array}$ & $\begin{array}{l}0.007 \\
(0.274)\end{array}$ & $\begin{array}{l}0.313^{* * *} \\
(7.942)\end{array}$ \\
\hline Tech & $\begin{array}{l}0.258 * * * \\
(3.089)\end{array}$ & $\begin{array}{l}0.258 * * * \\
(3.045)\end{array}$ & $\begin{array}{l}-0.002 \\
(-0.126)\end{array}$ & $\begin{array}{l}0.011 \\
(0.836)\end{array}$ & $\begin{array}{l}0.083 \\
(1.016)\end{array}$ & $\begin{array}{l}0.147 * \\
(1.783)\end{array}$ & $\begin{array}{l}0.050 * * * \\
(2.776)\end{array}$ & $\begin{array}{l}0.010 \\
(0.267)\end{array}$ \\
\hline IPO market condition & & & $\begin{array}{l}0.176^{* * *} * \\
(6.829)\end{array}$ & $\begin{array}{l}0.055^{* *} \\
(2.089)\end{array}$ & & & $\begin{array}{l}0.004 \\
(1.453)\end{array}$ & $\begin{array}{l}0.002 \\
(0.582)\end{array}$ \\
\hline Price revision & & & & $\begin{array}{l}0.457 * * * \\
(17.128)\end{array}$ & & & & $\begin{array}{l}1.046^{* * * *} \\
(8.145)\end{array}$ \\
\hline Constant & $\begin{array}{l}0.888 \\
(1.554)\end{array}$ & $\begin{array}{l}0.759 \\
(1.285)\end{array}$ & $\begin{array}{l}-0.151 * * * \\
(-2.998)\end{array}$ & $\begin{array}{l}0.088 * * * \\
(2.904)\end{array}$ & $\begin{array}{l}1.112 * * * \\
(2.907)\end{array}$ & $\begin{array}{l}0.730 \\
(1.235)\end{array}$ & $\begin{array}{l}-0.375^{*} \\
(-1.781)\end{array}$ & $\begin{array}{l}0.180 * * \\
(2.197)\end{array}$ \\
\hline Industry \& Year FE & Yes & Yes & Yes & Yes & Yes & Yes & Yes & Yes \\
\hline Observations & 1.905 & 1.913 & 1.906 & 1.906 & 2.292 & 2.315 & 2.292 & 2.292 \\
\hline Adjusted R-squared & 0.620 & 0.614 & 0.138 & 0.240 & 0.670 & 0.667 & 0.202 & 0.453 \\
\hline
\end{tabular}


Table 3

IPO valuations (Offer price) for IPOs with patents

Panel A/B/C shows estimates of OLS regressions of IPO valuations for the full sample period 1981-2006/for the sub-period 1981-1993/for the sub-period 19942006. The dependent variables are the offer valuation ratio, defined as offer price divided by sales per share from the fiscal year preceding the IPO date. Robust $\mathrm{t}$ statistics are reported in parentheses below coefficient estimates. To save the space, coefficients for other independent variables for Panels B and C are not reported and available upon request. We control for industry (based on the 2-digit primary SIC code) and year (based on IPO date) fixed effects. The superscripts $* * *, * *, *$ denote statistical significance at the $1 \%, 5 \%$ and $10 \%$ level, respectively, in two-tailed tests. All variables are defined in the Appendix.

\begin{tabular}{|c|c|c|c|c|c|c|c|}
\hline \multicolumn{8}{|c|}{ Panel A: Full sample period: 1981-2006 } \\
\hline \multirow[b]{2}{*}{ Explanatory variables } & \multicolumn{7}{|c|}{ Dependent variable: Offer valuation ratio - Ln(P/S) } \\
\hline & $(1)$ & $(2)$ & $(3)$ & $(4)$ & $(5)$ & $(6)$ & $(7)$ \\
\hline $\operatorname{Ln}($ Scaled Patent/Assets +1$)$ & $\begin{array}{l}1.100 * * * \\
(3.336)\end{array}$ & & $\begin{array}{l}0.900 * * \\
(2.345)\end{array}$ & & & $\begin{array}{l}0.825^{*} \\
(1.960)\end{array}$ & $\begin{array}{l}0.874 * * \\
(2.489)\end{array}$ \\
\hline $\operatorname{Ln}($ Scaled Citation/Assets +1$)$ & & $\begin{array}{l}0.479 * * * \\
(3.737)\end{array}$ & $\begin{array}{l}0.173 \\
(1.128)\end{array}$ & & & & \\
\hline $\operatorname{Ln}($ Innovation efficiency $-\mathrm{Pat}+1)$ & & & & $\begin{array}{l}0.301 * * * \\
(4.716)\end{array}$ & & $\begin{array}{l}0.109 \\
(1.112)\end{array}$ & \\
\hline $\operatorname{Ln}($ Innovation efficiency-Citaion +1$)$ & & & & & $\begin{array}{l}0.168 * * * \\
(3.672)\end{array}$ & & $\begin{array}{l}0.076 \\
(1.445)\end{array}$ \\
\hline $\mathrm{PS}_{\text {ind }}$ & $\begin{array}{l}0.108 \\
(1.298)\end{array}$ & $\begin{array}{l}0.094 \\
(1.122)\end{array}$ & $\begin{array}{l}0.108 \\
(1.295)\end{array}$ & $\begin{array}{l}0.093 \\
(1.059)\end{array}$ & $\begin{array}{l}0.095 \\
(1.081)\end{array}$ & $\begin{array}{l}0.106 \\
(1.214)\end{array}$ & $\begin{array}{l}0.109 \\
(1.247)\end{array}$ \\
\hline Ln(Proceeds) & $\begin{array}{l}0.036 \\
(0.680)\end{array}$ & $\begin{array}{l}0.027 \\
(0.493)\end{array}$ & $\begin{array}{l}0.040 \\
(0.742)\end{array}$ & $\begin{array}{l}0.074 \\
(1.278)\end{array}$ & $\begin{array}{l}0.061 \\
(1.040)\end{array}$ & $\begin{array}{l}0.069 \\
(1.182)\end{array}$ & $\begin{array}{l}0.069 \\
(1.184)\end{array}$ \\
\hline Prior industry-adjusted OPA & $\begin{array}{l}-1.955 * * * \\
(-6.614)\end{array}$ & $\begin{array}{l}-1.933 * * * \\
(-6.489)\end{array}$ & $\begin{array}{l}-1.943 * * * \\
(-6.588)\end{array}$ & $\begin{array}{l}-1.976^{* * *} * \\
(-6.022)\end{array}$ & $\begin{array}{l}-1.960 * * * \\
(-6.008)\end{array}$ & $\begin{array}{l}-1.986 * * * \\
(-6.154)\end{array}$ & $\begin{array}{l}-1.981 * * * \\
(-6.173)\end{array}$ \\
\hline Leverage & $\begin{array}{l}-0.272 * \\
(-1.686)\end{array}$ & $\begin{array}{l}-0.215 \\
(-1.389)\end{array}$ & $\begin{array}{l}-0.267 * \\
(-1.655)\end{array}$ & $\begin{array}{l}-0.219 \\
(-1.294)\end{array}$ & $\begin{array}{l}-0.203 \\
(-1.206)\end{array}$ & $\begin{array}{l}-0.261 \\
(-1.500)\end{array}$ & $\begin{array}{l}-0.263 \\
(-1.507)\end{array}$ \\
\hline $\mathrm{R} \& \mathrm{D}$ & $\begin{array}{l}1.609 * * * \\
(6.770)\end{array}$ & $\begin{array}{l}1.702 * * * \\
(7.219)\end{array}$ & $\begin{array}{l}1.596^{* * * *} \\
(6.766)\end{array}$ & $\begin{array}{l}1.868 * * * \\
(7.240)\end{array}$ & $\begin{array}{l}1.816 * * * \\
(7.181)\end{array}$ & $\begin{array}{l}1.592 * * * \\
(5.669)\end{array}$ & $\begin{array}{l}1.569 * * * \\
(5.972)\end{array}$ \\
\hline Growth & $\begin{array}{l}0.212 * * * \\
(9.396)\end{array}$ & $\begin{array}{l}0.215 * * * \\
(9.703)\end{array}$ & $\begin{array}{l}0.212 * * * \\
(9.404)\end{array}$ & $\begin{array}{l}0.210 * * * \\
(9.658)\end{array}$ & $\begin{array}{l}0.210 * * * \\
(9.687)\end{array}$ & $\begin{array}{l}0.206 * * * \\
(9.325)\end{array}$ & $\begin{array}{l}0.206 * * * \\
(9.284)\end{array}$ \\
\hline $\mathrm{VC}$ & $\begin{array}{l}0.329 * * * \\
(3.711)\end{array}$ & $\begin{array}{l}0.294 * * * \\
(3.269)\end{array}$ & $\begin{array}{l}0.321 * * * \\
(3.595)\end{array}$ & $\begin{array}{l}0.368 * * * \\
(3.690)\end{array}$ & $\begin{array}{l}0.315 * * * \\
(3.176)\end{array}$ & $\begin{array}{l}0.344 * * * \\
(3.403)\end{array}$ & $\begin{array}{l}0.326 * * * \\
(3.309)\end{array}$ \\
\hline Ln(Age) & $\begin{array}{l}-0.497 * * * \\
(-8.995)\end{array}$ & $\begin{array}{l}-0.512 * * * \\
(-9.159)\end{array}$ & $\begin{array}{l}-0.502 * * * \\
(-9.009)\end{array}$ & $\begin{array}{l}-0.563 * * * \\
(-9.139)\end{array}$ & $\begin{array}{l}-0.578 * * * \\
(-9.226)\end{array}$ & $\begin{array}{l}-0.561 * * * \\
(-9.085)\end{array}$ & $\begin{array}{l}-0.568 * * * \\
(-9.117)\end{array}$ \\
\hline Top IB & $\begin{array}{l}-0.017 \\
(-0.180)\end{array}$ & $\begin{array}{l}-0.061 \\
(-0.610)\end{array}$ & $\begin{array}{l}-0.021 \\
(-0.214)\end{array}$ & $\begin{array}{l}-0.052 \\
(-0.484)\end{array}$ & $\begin{array}{l}-0.077 \\
(-0.717)\end{array}$ & $\begin{array}{l}-0.030 \\
(-0.289)\end{array}$ & $\begin{array}{l}-0.034 \\
(-0.328)\end{array}$ \\
\hline Bubble & $\begin{array}{l}1.192 * * * \\
(4.615)\end{array}$ & $\begin{array}{l}1.096 * * * \\
(4.334)\end{array}$ & $\begin{array}{l}1.182 * * * \\
(4.582)\end{array}$ & $\begin{array}{l}1.174 * * * \\
(4.053)\end{array}$ & $\begin{array}{l}1.021 * * * \\
(3.618)\end{array}$ & $\begin{array}{l}1.201 * * * \\
(4.246)\end{array}$ & $\begin{array}{l}1.156 * * * \\
(4.038)\end{array}$ \\
\hline Tech & $\begin{array}{l}-0.059 \\
(-0.509)\end{array}$ & $\begin{array}{l}-0.061 \\
(-0.527)\end{array}$ & $\begin{array}{l}-0.063 \\
(-0.547)\end{array}$ & $\begin{array}{l}0.006 \\
(0.047)\end{array}$ & $\begin{array}{l}-0.025 \\
(-0.205)\end{array}$ & $\begin{array}{l}-0.028 \\
(-0.231)\end{array}$ & $\begin{array}{l}-0.039 \\
(-0.322)\end{array}$ \\
\hline Constant & $\begin{array}{l}1.379 * \\
(1.728)\end{array}$ & $\begin{array}{l}1.614 * * \\
(2.084)\end{array}$ & $\begin{array}{l}1.402^{*} \\
(1.751)\end{array}$ & $\begin{array}{l}1.351 * \\
(1.821)\end{array}$ & $\begin{array}{l}1.622 * * \\
(2.240)\end{array}$ & $\begin{array}{l}1.390 * \\
(1.793)\end{array}$ & $\begin{array}{l}1.454^{*} \\
(1.893)\end{array}$ \\
\hline Industry and Year FE & $\begin{array}{l}\text { Yes } \\
\text { Yes } 1.1201 \\
\end{array}$ & Yes & Yes & $\begin{array}{l}\text { Yes } \\
\text { Yez1) }\end{array}$ & Yes & Yes & $\begin{array}{l}\text { Yes } \\
\text { Yes }\end{array}$ \\
\hline Observations & 851 & 851 & 851 & 743 & 743 & 743 & 743 \\
\hline Adjusted R-squared & 0.707 & 0.703 & 0.708 & 0.691 & 0.689 & 0.695 & 0.695 \\
\hline
\end{tabular}




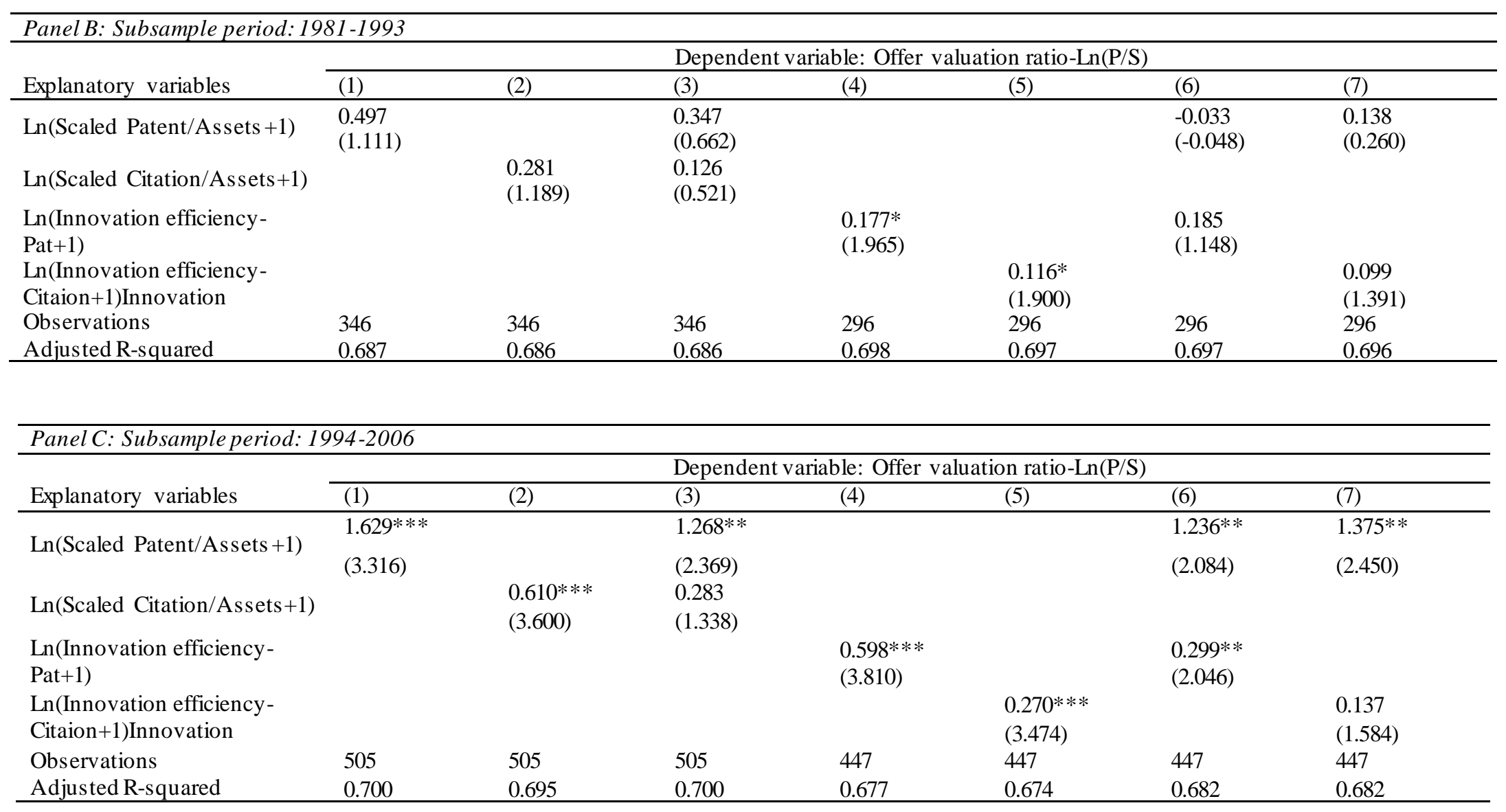




\section{Table 4}

\section{Initial returns of IPOs with patents}

This table shows estimates of OLS regressions of initial returns. The dependent variables are initial return s, defined as the closing price on the first trading day divided by the offer price, minus one. Robust t-statistics are reported in parentheses below coefficient estimates. We control for industry (based on 2 -digit primary SIC code) and year (based on IPO date) fixed effects. The superscripts ***, **, * denote statistical significance at the $1 \%$, $5 \%$ and $10 \%$ level, respectively, in two-tailed tests. All variables are defined in the Appendix.

\begin{tabular}{|c|c|c|c|c|c|c|c|}
\hline \multirow[b]{2}{*}{ Explanatory variables } & \multicolumn{7}{|c|}{ Dependent variables: Initial returns } \\
\hline & $(1)$ & $(2)$ & (3) & $(4)$ & $(5)$ & $(6)$ & $(7)$ \\
\hline Ln(Scaled Patent/Assets +1) & $\begin{array}{l}0.018 \\
(0.323)\end{array}$ & & $\begin{array}{l}0.002 \\
(0.034)\end{array}$ & & & $\begin{array}{l}0.040 \\
(0.563)\end{array}$ & $\begin{array}{l}0.009 \\
(0.140)\end{array}$ \\
\hline Ln(Scaled Citation/Assets +1$)$ & & $\begin{array}{l}0.014 \\
(0.474)\end{array}$ & $\begin{array}{l}0.013 \\
(0.337)\end{array}$ & & & & \\
\hline Ln(Innovation efficiency-Pat+1) & & & & $\begin{array}{l}-0.008 \\
(-0.473)\end{array}$ & & $\begin{array}{l}-0.017 \\
(-0.817)\end{array}$ & \\
\hline $\begin{array}{l}\text { Ln(Innovation efficiency- } \\
\text { Citaion+1) }\end{array}$ & & & & & $\begin{array}{l}0.003 \\
(0.242)\end{array}$ & & $\begin{array}{l}0.002 \\
(0.142)\end{array}$ \\
\hline Ln(Proceeds) & $\begin{array}{l}-(0.027 * \\
(-1.697)\end{array}$ & $\begin{array}{l}-(0.027 * \\
(-1.678)\end{array}$ & $\begin{array}{l}-(0.027 * \\
(-1.671)\end{array}$ & $\begin{array}{l}-0.022 \\
(-1.221)\end{array}$ & $\begin{array}{l}-0.020 \\
(-1.138)\end{array}$ & $\begin{array}{l}-0.023 \\
(-1.236)\end{array}$ & $\begin{array}{l}-0.020 \\
(-1.131)\end{array}$ \\
\hline Prior industry-adjusted OPA & $\begin{array}{l}0.072 \\
(0.745)\end{array}$ & $\begin{array}{l}0.073 \\
(0.756)\end{array}$ & $\begin{array}{l}0.073 \\
(0.755)\end{array}$ & $\begin{array}{l}0.076 \\
(0.689)\end{array}$ & $\begin{array}{l}0.076 \\
(0.687)\end{array}$ & $\begin{array}{l}0.076 \\
(0.691)\end{array}$ & $\begin{array}{l}0.076 \\
(0.686)\end{array}$ \\
\hline Leverage & $\begin{array}{l}-0.010 \\
(-0.347)\end{array}$ & $\begin{array}{l}-0.010 \\
(-0.332)\end{array}$ & $\begin{array}{l}-0.010 \\
(-0.335)\end{array}$ & $\begin{array}{l}-0.005 \\
(-0.135)\end{array}$ & $\begin{array}{l}-0.006 \\
(-0.194)\end{array}$ & $\begin{array}{l}-0.007 \\
(-0.202)\end{array}$ & $\begin{array}{l}-0.007 \\
(-0.213)\end{array}$ \\
\hline $\mathrm{R} \& \mathrm{D}$ & $\begin{array}{l}0.014 \\
(0.278)\end{array}$ & $\begin{array}{l}0.014 \\
(0.282)\end{array}$ & $\begin{array}{l}0.014 \\
(0.270)\end{array}$ & $\begin{array}{l}0.013 \\
(0.249)\end{array}$ & $\begin{array}{l}0.016 \\
(0.315)\end{array}$ & $\begin{array}{l}0.002 \\
(0.038)\end{array}$ & $\begin{array}{l}0.014 \\
(0.252)\end{array}$ \\
\hline Growth & $\begin{array}{l}0.011^{*} \\
(1.913)\end{array}$ & $\begin{array}{l}0.011^{*} \\
(1.928)\end{array}$ & $\begin{array}{l}0.011^{*} \\
(1.914)\end{array}$ & $\begin{array}{l}0.011^{*} \\
(1.946)\end{array}$ & $\begin{array}{l}0.011^{*} \\
(1.934)\end{array}$ & $\begin{array}{l}0.011^{*} \\
(1.897)\end{array}$ & $\begin{array}{l}0.011^{*} \\
(1.907)\end{array}$ \\
\hline $\mathrm{VC}$ & $\begin{array}{l}0.026 \\
(0.911)\end{array}$ & $\begin{array}{l}0.025 \\
(0.891)\end{array}$ & $\begin{array}{l}0.025 \\
(0.890)\end{array}$ & $\begin{array}{l}0.027 \\
(0.823)\end{array}$ & $\begin{array}{l}0.028 \\
(0.874)\end{array}$ & $\begin{array}{l}0.025 \\
(0.771)\end{array}$ & $\begin{array}{l}0.028 \\
(0.873)\end{array}$ \\
\hline Ln(Age) & $\begin{array}{l}-0.004 \\
(-0.356)\end{array}$ & $\begin{array}{l}-0.005 \\
(-0.393)\end{array}$ & $\begin{array}{l}-0.005 \\
(-0.391)\end{array}$ & $\begin{array}{l}-0.008 \\
(-0.546)\end{array}$ & $\begin{array}{l}-0.008 \\
(-0.581)\end{array}$ & $\begin{array}{l}-0.008 \\
(-0.534)\end{array}$ & $\begin{array}{l}-0.008 \\
(-0.573)\end{array}$ \\
\hline Top IB & $\begin{array}{l}0.007 \\
(0.216)\end{array}$ & $\begin{array}{l}0.007 \\
(0.205)\end{array}$ & $\begin{array}{l}0.007 \\
(0.206)\end{array}$ & $\begin{array}{l}0.009 \\
(0.246)\end{array}$ & $\begin{array}{l}0.010 \\
(0.288)\end{array}$ & $\begin{array}{l}0.010 \\
(0.280)\end{array}$ & $\begin{array}{l}0.011 \\
(0.296)\end{array}$ \\
\hline Bubble & $\begin{array}{l}0.395 * * * \\
(4.935)\end{array}$ & $\begin{array}{l}0.393 * * * \\
(4.938)\end{array}$ & $\begin{array}{l}0.393 * * * \\
(4.877)\end{array}$ & $\begin{array}{l}0.355^{* * *} * \\
(4.347)\end{array}$ & $\begin{array}{l}0.360 * * * \\
(4.380)\end{array}$ & $\begin{array}{l}0.356 * * * \\
(4.344)\end{array}$ & $\begin{array}{l}0.361 * * * \\
(4.337)\end{array}$ \\
\hline Tech & $\begin{array}{l}0.043 \\
(1.094)\end{array}$ & $\begin{array}{l}0.043 \\
(1.088)\end{array}$ & $\begin{array}{l}0.043 \\
(1.087)\end{array}$ & $\begin{array}{l}0.038 \\
(0.879)\end{array}$ & $\begin{array}{l}0.040 \\
(0.913)\end{array}$ & $\begin{array}{l}0.037 \\
(0.825)\end{array}$ & $\begin{array}{l}0.040 \\
(0.906)\end{array}$ \\
\hline IPO market condition & $\begin{array}{l}0.118 \\
(1.616)\end{array}$ & $\begin{array}{l}0.118 \\
(1.618)\end{array}$ & $\begin{array}{l}0.118 \\
(1.618)\end{array}$ & $\begin{array}{l}0.111 \\
(1.443)\end{array}$ & $\begin{array}{l}0.110 \\
(1.434)\end{array}$ & $\begin{array}{l}0.110 \\
(1.435)\end{array}$ & $\begin{array}{l}0.110 \\
(1.432)\end{array}$ \\
\hline Price revision & $\begin{array}{l}0.928 * * * \\
(12.165)\end{array}$ & $\begin{array}{l}0.927 * * * \\
(12.177)\end{array}$ & $\begin{array}{l}0.927 * * * \\
(12.156)\end{array}$ & $\begin{array}{l}0.945 * * * \\
(11.636)\end{array}$ & $\begin{array}{l}0.942 * * * \\
(11.753)\end{array}$ & $\begin{array}{l}0.946 * * * \\
(11.645)\end{array}$ & $\begin{array}{l}0.942 * * * \\
(11.715)\end{array}$ \\
\hline Constant & $\begin{array}{l}-0.041 \\
(-0.406)\end{array}$ & $\begin{array}{l}-0.038 \\
(-0.384)\end{array}$ & $\begin{array}{l}-0.039 \\
(-0.386)\end{array}$ & $\begin{array}{l}-0.019 \\
(-0.172)\end{array}$ & $\begin{array}{l}-0.033 \\
(-0.302)\end{array}$ & $\begin{array}{l}-0.016 \\
(-0.141)\end{array}$ & $\begin{array}{l}-0.034 \\
(-0.313)\end{array}$ \\
\hline $\begin{array}{l}\text { Industry and Year FE } \\
\text { Observations } \\
\text { Adjusted R-squared }\end{array}$ & $\begin{array}{l}\text { Yes } \\
844 \\
0.457 \\
\end{array}$ & $\begin{array}{l}\text { Yes } \\
844 \\
0.457 \\
\end{array}$ & $\begin{array}{l}\text { Yes } \\
844 \\
0.456 \\
\end{array}$ & $\begin{array}{l}\text { Yes } \\
737 \\
0.460 \\
\end{array}$ & $\begin{array}{l}\text { Yes } \\
737 \\
0.460 \\
\end{array}$ & $\begin{array}{l}\text { Yes } \\
737 \\
0.459 \\
\end{array}$ & $\begin{array}{l}\text { Yes } \\
737 \\
0.459 \\
\end{array}$ \\
\hline
\end{tabular}




\section{Table 5}

\section{Tobin's $Q$ for IPOs with patents}

This table shows estimates of OLS regressions of Tobin's $Q$. The dependent variables in Panel A/B/C are the natural logarithm of Tobin's Q measured at offer price (TobinQ_day0)/first trading day closing price (TobinQ_day1)/one year after IPO (TobinQ_year1). TobinQ_day0 is defined as the sum of the firm's market value of equity (offer price times the number of outstanding shares) and the book value of its total liabilities divided by the sum of book value of its total assets and IPO proceeds. TobinQ_day1 is defined similarly except that we use the first trading day closing price to calculate the market value of equity. IPO proceeds are the number of shares sold in the offering multiplied by the offer price. Book value of total assets and liabilities are for the fiscal year prior to IPO date. We add the IPO proceeds to the most recent book value of assets prior to the IPO. TobinQ_yearl is defined as the sum of the firm's market value of equity (fiscal year end closing price times the number of outstanding shares) and the book value of its total liabilities divided by the book value of its total assets. The fiscal year end closing price and book value of total assets and liabilities are for the one fiscal year after the IPO date. In Panels A and B, the covariates of IPO financials are measured for the fiscal year prior to the IPO. In Panel C, the covariates of IPO firm financials are measured for the IPO year. Robust t-statistics are reported in parentheses below coefficient estimates. To save the space, coefficients for other independent variables (Ln (Proceeds), Prior industry-adjusted OPA, Leverage, R\&D, Capital Intensity, VC, Ln (Age), Top IB, Bubble, and Tech) are not reported and available upon request. We control for industry (based on the 2-digit primary SIC code) and year (based on the IPO date) fixed effects. The superscripts $* * *, * *, *$ denote statistical significance at the $1 \%, 5 \%$ and $10 \%$ level, respectively, in two tailed tests. All variables are defined in the Appendix. 


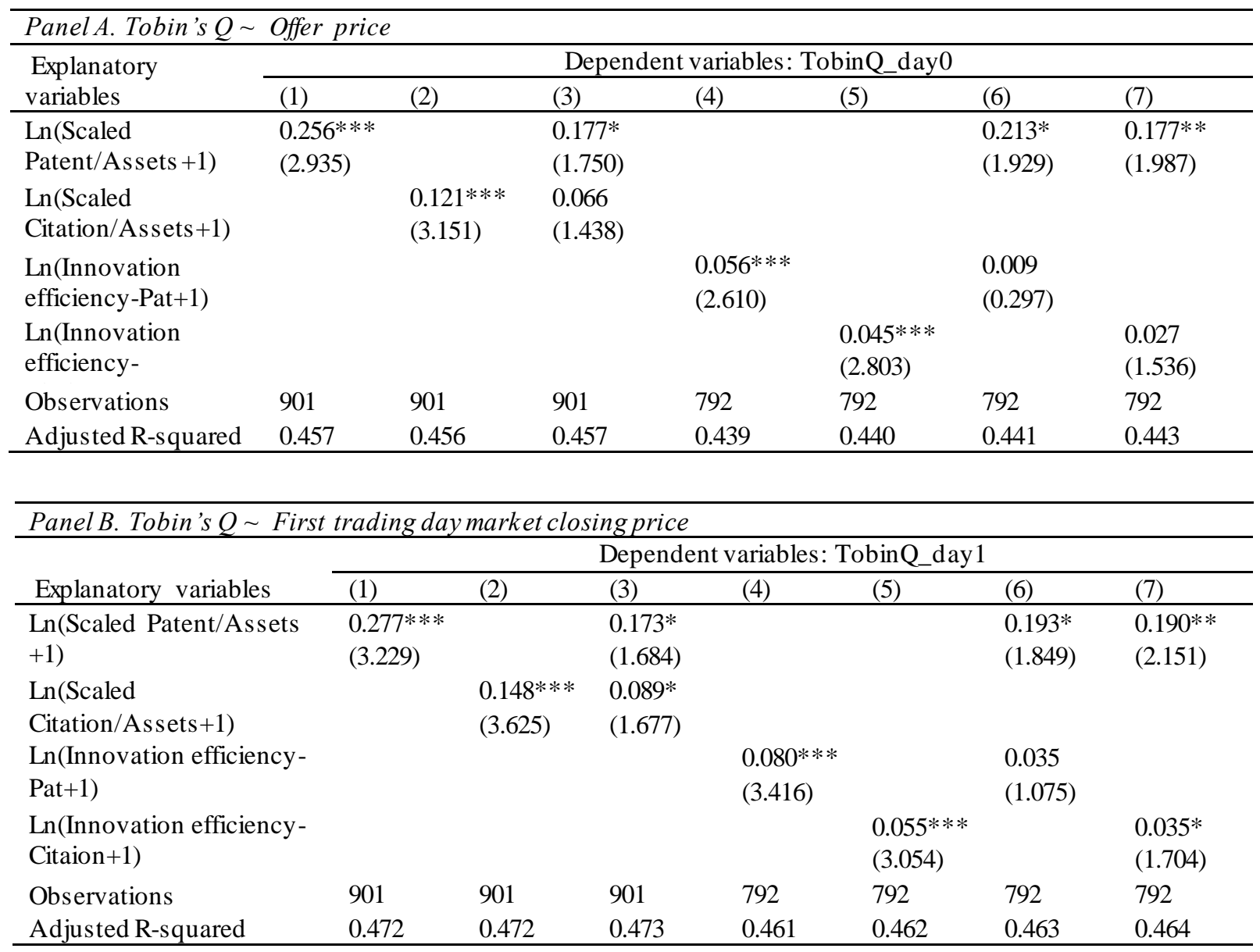

\begin{tabular}{llllllll}
\hline Panel C. Tobin's $Q \sim$ Market price one year after offering \\
\cline { 2 - 8 } & \multicolumn{7}{c}{ Dependent variables: TobinQ_year1 } \\
\cline { 2 - 8 } Explanatory variables & $(1)$ & $(2)$ & $(3)$ & $(4)$ & $(5)$ & $(6)$ & $(7)$ \\
\hline Ln(Scaled Patent/Assets & $0.469^{* * *}$ & & $0.339^{* *}$ & & & $0.407^{* * *}$ & $0.407^{* * *}$ \\
$+1)$ & $(3.521)$ & & $(2.106)$ & & & $(2.709)$ & $(2.942)$ \\
Ln(Scaled & & $0.235^{* * *}$ & 0.113 & & & & \\
Citation/Assets+1) & & $(4.010)$ & $(1.516)$ & & & & \\
Ln(Innovation efficiency- & & & & $0.107^{* *}$ & & 0.018 & \\
Pat+1) & & & $(2.561)$ & & $0.352)$ & \\
Ln(Innovation efficiency- & & & & & $0.056^{* *}$ & & 0.017 \\
Citaion+1) & & & & & $(2.002)$ & & $(0.564)$ \\
Observations & 863 & 863 & 863 & 754 & 754 & 754 & 754 \\
Adjusted R-squared & 0.194 & 0.190 & 0.195 & 0.172 & 0.170 & 0.182 & 0.182 \\
\hline
\end{tabular}


Table 6

\section{Long run performances of IPOs with patents}

This table shows estimates of OLS regressions of long-run performances for IPO firms with patents. The dependent variables for column (A) are buy-and-hold abnormal returns for each IPO following the IPO month $(\mathrm{T}=12,24$, and 36). The dependent variables for column (B) are industry-adjusted operating income before depreciation on assets (OPA) from one to three years after IPO. The industry adjusted OPA is defined as the difference between an IPO's OPA and the median value of the same two-digit SIC industry's OPA. The OPA is defined as the operating income before depreciation (OIBD) divided by total as sets. Year 0 represents the IPO year. Robust $\mathrm{t}$-statistics are reported in parentheses below coefficient estimates. The superscripts $* * *, * *, *$ denote statistical significan ce at the $1 \%, 5 \%$ and $10 \%$ level, respectively, in two-tailed tests. All variables are defined in the Appendix.

(A) Dependent variables: BHAR

(B) Dependent variables: Post-IPO Industryadjusted OPA

\begin{tabular}{|c|c|c|c|c|c|c|}
\hline Explanatory variables & Month $(1,12)$ & Month $(1,24)$ & Month $(1,36)$ & Year +1 & Year +2 & Year +3 \\
\hline Ln(Scaled Patent/Assets +1) & $\begin{array}{c}0.202 \\
(1.421)\end{array}$ & $\begin{array}{c}0.069 \\
(0.262)\end{array}$ & $\begin{array}{c}0.116 \\
(0.395)\end{array}$ & $\begin{array}{c}-0.112 \\
(-1.115)\end{array}$ & $\begin{array}{c}-0.102 \\
(-1.226)\end{array}$ & $\begin{array}{c}-0.100 \\
(-0.944)\end{array}$ \\
\hline Ln(Scaled Citation/Assets +1$)$ & $\begin{array}{c}-0.019 \\
(-0.235)\end{array}$ & $\begin{array}{c}0.048 \\
(0.281)\end{array}$ & $\begin{array}{l}0.025 \\
(0.145)\end{array}$ & $\begin{array}{c}0.017 \\
(0.515)\end{array}$ & $\begin{array}{l}-0.000 \\
(-0.014)\end{array}$ & $\begin{array}{c}0.019 \\
(0.308)\end{array}$ \\
\hline Prior industry-adjusted OPA & $\begin{array}{c}0.253 \\
(1.351)\end{array}$ & $\begin{array}{c}0.367 \\
(0.976)\end{array}$ & $\begin{array}{c}0.233 \\
(0.548)\end{array}$ & $\begin{array}{c}0.656^{* * *} * \\
(10.236)\end{array}$ & $\begin{array}{c}0.524 * * * \\
(7.116)\end{array}$ & $\begin{array}{c}0.435 * * * \\
(4.611)\end{array}$ \\
\hline Leverage & $\begin{array}{c}-0.043 \\
(-0.601)\end{array}$ & $\begin{array}{c}-0.111 \\
(-0.761)\end{array}$ & $\begin{array}{c}-0.188 \\
(-1.382)\end{array}$ & $\begin{array}{l}-0.020 \\
(-0.387)\end{array}$ & $\begin{array}{c}0.027 \\
(0.638)\end{array}$ & $\begin{array}{c}0.002 \\
(0.050)\end{array}$ \\
\hline $\mathrm{R} \& \mathrm{D}$ & $\begin{array}{c}0.042 \\
(0.379)\end{array}$ & $\begin{array}{c}0.162 \\
(0.806)\end{array}$ & $\begin{array}{c}0.002 \\
(0.010)\end{array}$ & $\begin{array}{c}-0.231 * * * \\
(-3.461)\end{array}$ & $\begin{array}{c}-0.214 * * * \\
(-3.640)\end{array}$ & $\begin{array}{c}-0.241 * * * \\
(-2.933)\end{array}$ \\
\hline Growth & $\begin{array}{c}0.014 \\
(0.895)\end{array}$ & $\begin{array}{c}0.005 \\
(0.444)\end{array}$ & $\begin{array}{l}-0.008 \\
(-0.616)\end{array}$ & $\begin{array}{c}0.002 \\
(0.637)\end{array}$ & $\begin{array}{l}-0.007 \\
(-1.416)\end{array}$ & $\begin{array}{c}-0.008 \\
(-1.324)\end{array}$ \\
\hline $\mathrm{VC}$ & $\begin{array}{c}0.044 \\
(0.823)\end{array}$ & $\begin{array}{c}0.121 \\
(0.893)\end{array}$ & $\begin{array}{c}0.167 \\
(1.281)\end{array}$ & $\begin{array}{c}-0.018 \\
(-0.821)\end{array}$ & $\begin{array}{c}-0.009 \\
(-0.359)\end{array}$ & $\begin{array}{c}0.011 \\
(0.378)\end{array}$ \\
\hline Ln(Age) & $\begin{array}{l}0.053^{*} \\
(1.875)\end{array}$ & $\begin{array}{l}0.070 \\
(1.215)\end{array}$ & $\begin{array}{l}0.075 \\
(1.185)\end{array}$ & $\begin{array}{c}0.053 * * * \\
(4.875)\end{array}$ & $\begin{array}{c}0.040 * * * \\
(3.577)\end{array}$ & $\begin{array}{c}0.051 * * * \\
(3.985)\end{array}$ \\
\hline Top IB & $\begin{array}{c}0.165^{* * *} * \\
(3.172)\end{array}$ & $\begin{array}{l}0.250^{*} \\
(1.769)\end{array}$ & $\begin{array}{c}0.353^{* *} * \\
(2.581)\end{array}$ & $\begin{array}{l}0.038^{*} \\
(1.855)\end{array}$ & $\begin{array}{l}0.036^{*} \\
(1.739)\end{array}$ & $\begin{array}{c}0.068 * * * \\
(2.606)\end{array}$ \\
\hline Bubble & $\begin{array}{c}-0.591 * * * \\
(-4.402)\end{array}$ & $\begin{array}{c}-0.978 * * * \\
(-2.922)\end{array}$ & $\begin{array}{c}-1.075 * * * \\
(-3.545)\end{array}$ & $\begin{array}{l}-0.012 \\
(-0.191)\end{array}$ & $\begin{array}{l}-0.083 \\
(-1.055)\end{array}$ & $\begin{array}{c}-0.051 \\
(-0.525)\end{array}$ \\
\hline Tech & $\begin{array}{c}-0.039 \\
(-0.544)\end{array}$ & $\begin{array}{c}0.201 \\
(1.512)\end{array}$ & $\begin{array}{c}0.210 \\
(1.339)\end{array}$ & $\begin{array}{l}0.063^{*} \\
(1.789)\end{array}$ & $\begin{array}{c}0.046 \\
(1.350)\end{array}$ & $\begin{array}{c}0.021 \\
(0.537)\end{array}$ \\
\hline Constant & $\begin{array}{c}-0.554 * * * \\
(-2.623)\end{array}$ & $\begin{array}{c}-0.545 \\
(-1.424)\end{array}$ & $\begin{array}{l}-0.492 \\
(-1.357)\end{array}$ & $\begin{array}{l}-0.145 \\
(-1.376)\end{array}$ & $\begin{array}{l}-0.109 \\
(-1.122)\end{array}$ & $\begin{array}{c}-0.089 \\
(-0.739)\end{array}$ \\
\hline $\begin{array}{l}\text { Industry and Year FE } \\
\text { Observations } \\
\text { Adjusted R-squared }\end{array}$ & $\begin{array}{c}\text { Yes } \\
834 \\
0.038\end{array}$ & $\begin{array}{l}\text { Yes } \\
834 \\
0.036\end{array}$ & $\begin{array}{c}\text { Yes } \\
834 \\
0.020\end{array}$ & $\begin{array}{l}\text { Yes } \\
815 \\
0.295\end{array}$ & $\begin{array}{l}\text { Yes } \\
755 \\
0.260\end{array}$ & $\begin{array}{l}\text { Yes } \\
695 \\
0.170\end{array}$ \\
\hline
\end{tabular}




\section{Appendix: Variable definitions}

Panel A: Patent metrics

The scaled number of patents granted in the five years before the IPO date. First, for

Scaled Patent each technology class defined by USPTO and patent grant year, we compute the average number of granted patents of all firms. Second, we scale the number of granted patents to the firm in a technology class in that year by the corresponding average value from the first step. Third, for each firm, we sum the scaled number from the second step

The citation count is the number of citations a patent receives upon its approval to the IPO year. We adjust for time and technology variation by scaling each patent citation count by the average of citations received by all patents granted in the same year and

Scaled Citation technology class defined by USPTO. For firm $i$, we compute $C_{i k}^{j}$, the number of citations received in year $\mathrm{j}(\mathrm{j}=\max (-5$, grant year-IPO year) to $\mathrm{j}=0$, year 0 is the IPO year) by patent $\mathrm{k}$, scaled by the average number of citations received in year $\mathrm{j}$ by all patents of the same technology class granted in the same year. Second, we sum scaled citations for IPO firm i's patents granted over the previous five years before the IPO date as follows: Scaled Citation $t=\sum_{i=\max (-5, \text { grant vear-IPO vear })}^{0} \sum_{\mathrm{k}=1}^{\mathrm{N}_{\mathrm{j}}} \mathrm{C}_{\mathrm{ik}}^{\mathrm{j}}$.

Innovation The scaled number of patents (Scaled Patent) divided by R\&D expenses in the year prior efficiency- Pat to the IPO date.

Innovation The scaled current citations (Scaled Citation) divided by R\&D expenses in the year prior efficiency-Citation to the IPO date.

Panel B: Firm characteristics

Age

The number of years between incorporation and the IPO date. Firms' incorporation dates are from http://bear.warrington.ufl.edu/ritter/ipodata.htm.

Prior industryThe difference between an IPO's OPA and the median value of the same two-digit SIC

adjusted OPA industry's OPAs for the fiscal year prior to the IPO date. The OPA is defined as the operating income before depreciation (OIBD) divided by total as sets.

Leverage

$\mathrm{R} \& \mathrm{D}$

The sum of long-term debt and debt in current liabilities divided by total as sets.

Growth dhe

Assets The sales growth rate from the year prior to the IPO to the IPO year.

Total as sets in the fiscal year prior to the IPO date in millions. 
Panel C: Issue characteristics

Patent

$\mathrm{PS}_{\text {ind }}$

Proceeds

$\mathrm{VC}$

Top IB

Bubble

Tech

IPO market

condition

Expected valuation ratio

Offer valuation ratio

TobinQ_day0

TobinQ_day1

TobinQ_year1

Price revisions

Initial returns
A dummy variable that equals one if firms have at least one patent granted in the five years before their IPO dates and zero otherwise.

Industry median of P/S (market value of equity divided by total sales) based on the twodigit primary SIC code during the is suer's IPO year.

The number of shares sold in the offering multiplied by the offer price.

A dummy variable that equals one if firms are backed by venture capitalists before IPOs and zero otherwise.

A dummy variable that equals one if the lead underwriter's updated Carter and Manaster rank (Loughran and Ritter (2004)) is 8 or more and zero otherwise.

A dummy variable that equals one if the IPO occurred during the period 1999-2000 and zero otherwise.

A dummy variable that equals one if the firm is defined as a Tech firm in Loughran and Ritter (2004) and zero otherwise.

The average initial returns of IPOs within the same two-digit primary SIC code industry of the sample IPO between a firm's IPO filing date and its IPO date.

The expected offer price divided by sales per share from the fiscal year preceding the IPO date. The expected offer price is the midpoint of the initial price range.

The offer price divided by sales per share from the fiscal year preceding the IPO date.

The sum of the firm's market value of equity (offer price times the number of outstanding shares) and the book value of its total liabilities divided by the sum of the book value of its total assets and IPO proceeds. The book values of total as sets and liabilities are for the fiscal year prior to the IPO date.

The sum of the firm's market value of equity (first trading day closing price times the number of outstanding shares) and the book value of its total liabilities divided by the sum of book value of its total as sets and IPO proceeds. Book values of total as sets and liabilities are for the fiscal year prior to IPO date.

The sum of the firm's market value of equity (fiscal year end closing price times the number of outstanding shares) and the book value of its total liabilities divided by the book value of its total as sets. The fiscal year end closing price and book value of total assets and liabilities are for the one fiscal year after the IPO date.

The offer price divided by the mid-point of filing price range minus one.

The first trading day closing price divided by the offer price minus one. 